\title{
Social and ecological effectiveness of large marine protected areas
}

\section{Natalie C. Ban ${ }^{\mathrm{a}}$, Tammy E. Davies ${ }^{\mathrm{a}}$, Stacy E. Aguilera ${ }^{\mathrm{b}}$, Cassandra Brooks ${ }^{\mathrm{c}}$, Michael Cox ${ }^{\mathrm{d}}$, Graham Epstein $^{\mathrm{e}}$, Louisa S. Evans ${ }^{\mathrm{f}}$, Sara M. Maxwell ${ }^{\mathrm{g}}$, Mateja Nenadovic ${ }^{\mathrm{h}}$}

${ }^{a}$ School of Environmental Studies, University of Victoria, PO Box 1700 STN CSC, Victoria BC V8W 2Y2, Canada.

${ }^{\mathrm{b}}$ The Leonard and Jayne Abess Center for Ecosystem Science and Policy, University of Miami, 1365 Memorial Drive, Ungar Building 230M, Coral Gables, FL 33124, USA

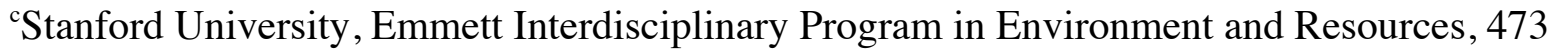

Via Ortega, Y2E2 Suite 226, Stanford, CA 94305, USA

'Environmental Studies Program, Dartmouth College, 6182 Steele Hall, Hanover, NH 03755, USA

'Environmental Change and Governance Group, School of Environment, Resources and Sustainability, University of Waterloo, 200 University Avenue West, Waterloo, ON, N2L 3G1 Canada

${ }^{\mathrm{f}}$ Geography, College of Life and Environmental Sciences, University of Exeter, Exeter EX4 4RJ, United Kingdom

'Department of Biological Sciences, Old Dominion University, 5115 Hampton Boulevard, Norfolk, VA 23529, USA

${ }^{\mathrm{h}}$ Duke University Marine Laboratory, Nicholas School of the Environment, Duke University, 135 Duke Marine Lab Road, Beaufort, NC 28516, USA 


\begin{abstract}
Large marine protected areas are increasingly being established to meet global conservation targets and promote sustainable use of resources. Although the factors affecting the performance of small-scale marine protected areas are relatively well studied, there is no such body of knowledge for large marine protected areas. We conducted a global meta-analysis to systematically investigate social, ecological, and governance characteristics of successful large marine protected areas with respect to several social and ecological outcomes. We included all large $(>10,000 \mathrm{~km} 2)$, implemented ( $>5$ years of active management) marine protected areas that had sufficient data for analysis, for a total of twelve cases. We used the Social-Ecological Systems Meta-Analysis Database, and a consistent protocol for using secondary data and key informant interviews, to code proxies for fisheries, ecosystem health, and the wellbeing of user groups (mainly fishers). We tested four sets of hypotheses derived from the literature on smallscale marine protected areas and common-pool resources: (i) the attributes of species and ecosystems to be managed in the marine protected area, (ii) adherence to principles for designing small-scale marine protected areas, (iii) adherence to the design principles for common-pool resource management, and (iv) stakeholder participation. We found varying levels of support for these hypotheses. Improved fisheries were associated with older marine protected areas, and higher levels of enforcement. Declining fisheries were associated with several ecological and economic factors, including low productivity, high mobility, and high market value. High levels of participation were correlated with improvements in wellbeing and ecosystem health trends. Overall, this study constitutes an important first step in identifying factors affecting social wellbeing and ecological performance of large marine protected areas.
\end{abstract}




\section{Introduction}

Global concerns about declines in marine biodiversity (Cheung et al. 2009) have led to increasing commitments to establish marine protected areas (MPAs) (Convention on Biological Diversity 2010). Marine protected areas - "a clearly defined geographical space, recognised, dedicated and managed, through legal or other effective means, to achieve the long-term conservation of nature with associated ecosystem services and cultural values" (Day et al. 2012) - have been used as a resource and biodiversity conservation tool for centuries (Johannes 2002). Although most MPAs are relatively small in size (median size $3.3 \mathrm{~km}^{2}$; Boonzaier and Pauly 2016), recent years have seen an increase in the designation of very large MPAs (Boonzaier and Pauly 2016).

Large MPAs (LMPAs, also referred to as large-scale MPAs), some of which exceed one million $\mathrm{km}^{2}$, have become a high profile marine conservation strategy that now constitute a disproportionate proportion of the ocean's protected area and have moved us closer to achieving international biodiversity targets (e.g., Aichi Target 11; Boonzaier and Pauly 2016). LMPAs differ from small-scale MPAs because they encompass more extensive areas, including biologically connected ecosystems, and a greater diversity of habitats, including pelagic and deep benthic areas (Wagner et al. 2013), as well as different human dimensions, that may include a greater number or diversity of human populations (Gruby et al. 2016). Thus, LMPAs have unique management requirements and challenges, including education and enforcement over vast areas, and management of dynamic seascapes (Maxwell et al. 2014). The primary objective of LMPAs is biodiversity conservation (Day et al. 2012), although they may take a variety of forms 
(e.g., no-take, multi-use, etc.) and also have other goals, such as social and economic (Wilhelm et al. 2014). As yet, no study has empirically evaluated different outcomes of LMPAs.

The contributions of LMPAs to biodiversity conservation are debated. Proponents argue that very large protected areas are essential for meeting global marine conservation targets (e.g., Aichi Target 11), are ecologically critical because they encompass entire ecosystems, enable synergistic links to adjacent ecosystems (Toonen et al. 2011; Sheppard et al. 2012), and may be more resilient to large-scale disturbances (McLeod et al. 2009; Toonen et al. 2013). Furthermore, they are thought to provide benefits to wide-ranging species, such as seabirds and tunas (Maxwell and Morgan 2013; Young et al. 2015). However it has also been argued that LMPAs may contribute more to political targets rather than biodiversity conservation (Devillers et al. 2015). While both of these arguments are potentially valid, there is a large and growing need to better understand factors influencing the effectiveness of LMPAs, particularly on the diverse social and ecological outcomes these areas are expected to achieve.

Given the rapid increase in the number and total size of LMPAs (Boonzaier and Pauly 2016; S1), empirical investigations of their effectiveness are urgently needed to validate the development and maintenance of such areas. More specifically, understanding the social, ecological, and governance mechanisms that contribute to outcomes (e.g., protecting marine species, restoring fish stocks, minimizing conflicts among user groups) would help improve management of existing LMPAs and inform the establishment of others (Gruby et al. 2016). Fortunately, there is an abundance of research from related literatures - especially MPA design and common-pool resources - that can provide guidance regarding potentially influential factors. For example, 
recent studies demonstrate the importance of the ecological and economic attributes of species and ecosystems being managed: systems or species that are more productive, resilient, less mobile, sheltered from major markets, and have lower market value are more likely to have a positive response to protection (Claudet et al. 2010; Collette et al. 2011a). The attributes of the MPA have also been shown to influence outcomes: a recent study found that MPAs that include no-take areas, are well-enforced, old ( $>10$ years), large $\left(>100 \mathrm{~km}^{2}\right)$, and isolated are more likely to be ecologically effective (i.e. as measured through higher fish biomass) (Edgar et al. 2014). In addition, a growing body of research and guidance on MPA design argues that MPAs or MPA networks that are explicitly designed to be comprehensive, adequate, and representative are more likely to be ecologically effective (Margules and Pressey 2000).

The social and governance attributes of MPAs have also been shown to play a critical role in conservation outcomes. First, the literature on common pool resources provides insights on several institutional factors collectively known as the "institutional design principles" (Ostrom 1990; Cox et al. 2010) that could affect the performance of MPAs. This literature suggests that the persistence of governance arrangements - and hence resource sustainability - is more likely in the presence of one or more of a number of facilitating conditions, including: clearly defined boundaries of the resource (e.g., the MPA, and resources within it) and the actors eligible to extract resources therein; the fit between rules and the attributes of the problems they are meant to address; monitoring of users and ecological conditions; sanctioning of rule-breakers; conflict resolution mechanisms; and coordination among jurisdictions for larger systems (Ostrom 1990; Cox et al. 2010). Second, stakeholder participation is widely considered essential for effective management of natural resources (Berkes 2009). In the context of MPAs and fisheries, direct and active involvement of fishers in the decision making process often enhances their willingness to 
negotiate agreements and comply with the subsequent rules and regulations (McCay and Jentoft 1996; White et al. 2002). And critically, a lack of such engagements has been identified as one of the key components contributing to poor performance of many MPAs throughout the world (Ferse et al. 2010).

Our aim is to assess the social and ecological performance of LMPAs $\left(>10,000 \mathrm{~km}^{2}\right)$. To focus our investigation, we identified factors demonstrated to influence outcomes at small-scales, and grouped them into four thematic hypotheses based on their origin in the literature: 1) Ecological and economic attributes of the species or ecosystem; 2) Attributes of the MPA; 3) Institutional design principles; and 4) Participation (S2). Our study is the first to empirically examine outcomes in LMPAs, and provides insights that can help guide management of current and future LMPAs.

\section{Methods}

\subsection{Selection of cases: LMPAs were selected for analysis based upon 1) biodiversity} conservation as a primary goal; 2) large size, defined as $>10,000 \mathrm{~km}^{2}$ because it encompasses MPAs several magnitudes larger than the median size $3.3 \mathrm{~km}^{2}$ (Boonzaier and Pauly 2016); 3) more than five years of active management (defined as having legislation and/or management plans in place, and some actions to implement these); five years - to provide enough time for ecological and social effects of management to be evident (Halpern and Warner 2002), our cutoff was 2014 when coding was started; and 4) enough data available to assess key outcomes. We selected LMPAs from MPAtlas.org (Marine Conservation Institute 2015) based on goal, size and age criteria, and then conducted a preliminary literature search to determine whether 
management actions were occurring, and the level of data available. Globally, 16 MPAs met the first three of our criteria. Four were excluded because they either lacked active management or adequate data on outcomes, resulting in a final sample of 12 MPAs (Figure 1; see S1 for a complete list of LMPAs, including those that did not meet our criteria).

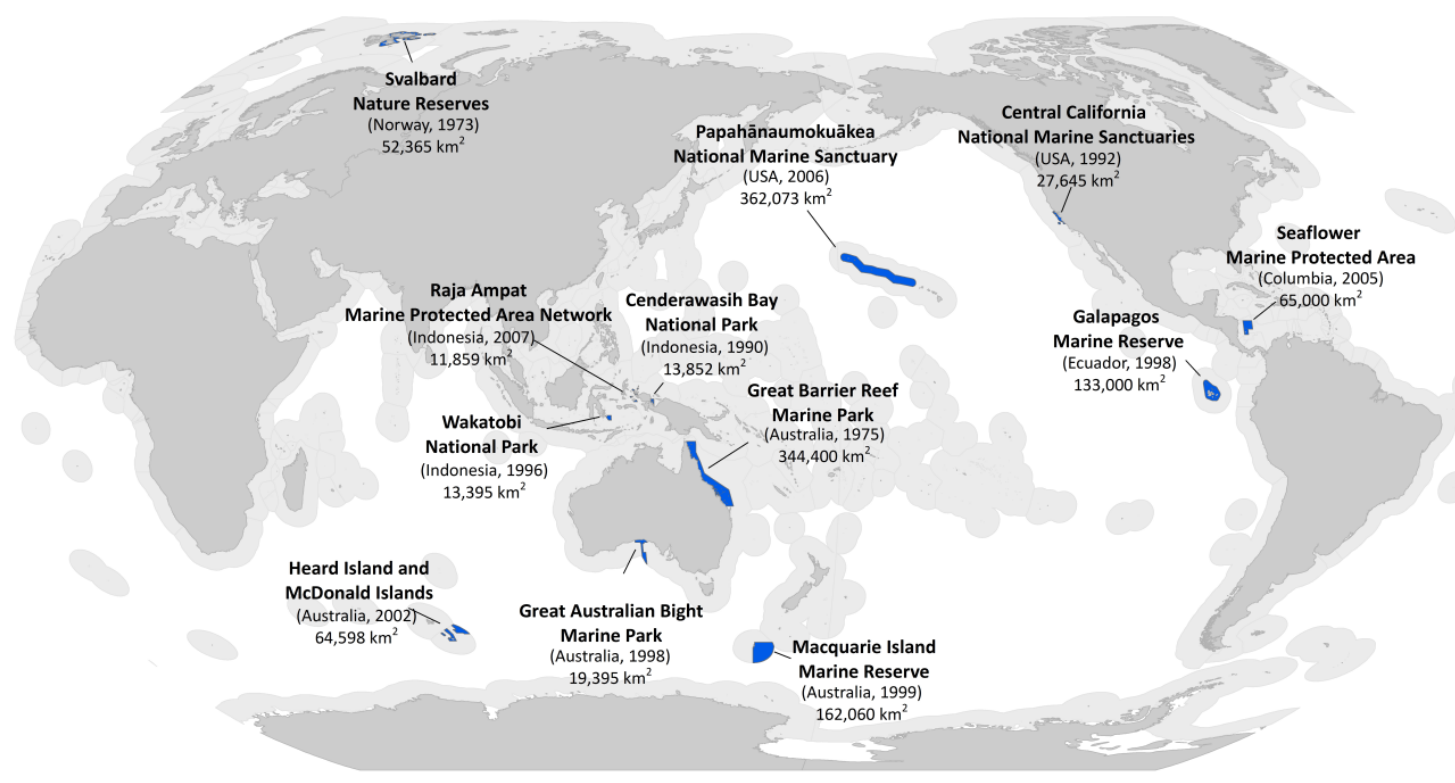

Figure 1. MPA name, country of origin, date designated, and total size of large MPAs used in this study, (see $\mathrm{S} 1$ for complete list of LMPAs).

\subsection{Coding framework: The Social-Ecological Systems Meta-Analysis Database (SESMAD)}

(Cox 2014) was used to structure our investigation and provide a consistent approach for coding the 12 LMPA cases. SESMAD is structured around the social-ecological systems framework (Ostrom 2009b), which recognises that actor groups influence social and ecological outcomes through interactions between the governance systems, other actor groups, and environmental commons (Cox 2014). For each LMPA, we coded one or more governance system (the act or management plan(s) that provides the framework for management of the MPA), an actor group (one manager group that implements the governance system, and at least one user group 
dependent on marine resources, typically a fisher, where such users were present), and two components relating to the ecological system: a proxy for ecosystem health, and a proxy for fished species. We refer to these proxies as "environmental commons" because they relate to the resource systems or units being managed. Both proxies were selected based on a) measurability: availability of data on condition trends over time; and b) sensitivity: ability to reflect general trends at the scale of the MPA (e.g., a proxy for ecosystem health was chosen based on its ability to reflect the overall ecosystem integrity of the MPA, such as coral cover, or a higher trophiclevel species). Interactions were structured around the environmental commons, creating two interactions for each MPA: one for the fished species proxy and another for the ecosystem health proxy. Each MPA was coded for a time period where management was relatively consistent, referred to as a 'snapshot' (e.g. major legislative changes or policy reforms would be coded as a separate snapshot). Thus, each interaction focussed on a specific snapshot, and included the key components (governance system, actor groups) that most directly interact with the selected environmental commons at the scale of the MPA.

2.3. Coding approach: For each LMPA, we conducted a detailed literature review, including peer-reviewed studies, management plans, government publications, and NGO reports. LMPAs varied in the documentation available; we provide a summary of confidence in the data in Table 1 (level of documentation). From the literature review, we identified the most influential or impactful governance system, user group, and manager for each interaction. We then added these key components to SESMAD (S3), with variables coded using knowledge from secondary data identified in the detailed literature review, as far as possible. Most variables were categorical (e.g., high, medium, low); the categorical nature of the data allowed us to compare across cases 
where different metrics might be used for the same variable. We then verified the choice of components coded for each LMPA, and the general trends through semi-structured interviews with one or more key informants for each LMPA. Key informants were identified using the following criteria: long ( $>5$ years) involvement in management of the LMPA, and having published on the LMPA. Both of these criteria were aimed at identifying key informants who could provide an overview of experiences and different perspectives of the LMPA, rather than providing a sectoral perspective. The main purpose of these interviews was to gain an understanding of how the LMPA was operating 'on-the-ground' and to sense-check findings. Interviews were not a primary source of data for the variables used in this study

2.4 Inter-coder reliability: We used several approaches to ensure inter-coder reliability: 1) we developed clear descriptions of the variables being coded (S2); 2) all cases were coded by pairs of coders, to allow two people to gain in-depth understanding of the case, and discuss the coding process; 3) we held regular discussions among the research team to ensure consistent interpretation of variables across cases.

2.5 Variables coded: We coded two key outcome variables for the snapshot being assessed in each case. Outcome variables were: 1 ) the trend in the condition of the environmental commons (fished species and ecosystem health proxies; options are decreased, remained the same, and increased); and 2) the trend in the wellbeing of the user group dependent on the fishery has changed; options are declined, remained the same, improved. We selected potential explanatory variables to test four thematic hypotheses (also referred to as "theories" by Cox et al. 2016; S2). We use hypotheses to refer to proposed relationships between factors and outcomes in marine 
protected areas or common pool resources as suggested in the literature; and we refer to them as thematic hypotheses because we have grouped factors based on their origin in the literature.

2.6 Data Analyses: All analyses were conducted using R (version 3.2.2; R Core Team 2015). To test for any association between our four thematic hypotheses and MPA outcomes (trends in fisheries, ecosystem health, and wellbeing) we used a Multiple Correspondence Analysis (MCA) for the categorical variables, and Principal Components Analysis (PCA) for the continuous variables, using the FactoMineR package (Husson et al. 2015). Both methods are conceptually similar; their main objective is to simplify the data by reducing the dimensionality of the dataset to reveal relationships (Lê et al. 2008). These methods reduce complex sets of variables into dimensions that comprise subsets of variables (that are correlated with one another, but relatively independent of other variables) to represent the variation in the data, and can be interpreted as representing underlying factors that lead to patterns in responses. Each of the three outcomes (trends in fisheries, ecosystem health, and wellbeing) were analysed with respect to the four sets of hypotheses. Response variables (outcomes) are included as 'supplementary variables' in MCA and PCA to assist in data interpretation (Lê et al. 2008). The variables for each hypothesis (predictor variables) were included as 'active' variables in the analysis, meaning that they contribute to the formation of the dimensions. The outcome of interest was included as a 'supplementary variable', because these variables are not involved in the formation of dimensions but are overlaid onto the same space; any association between active and supplementary (response) variables indicates there is a strong correlation (i.e., between the predictor and response variables) (Husson et al. 2010). We assessed relationships in the data both visually using biplots with confidence ellipses for the outcomes, and analytically using the 
dimdesc function (Husson et al. 2015) to extract all variables with a significant contribution $(\mathrm{p}<0.10)$ to the first two dimensions. This function provides the correlation coefficient, and also performs a test to determine if the variables and the variable categories are significant (Husson et al. 2010). All cases were included in the analyses as appropriate. Prior to analysis, any variables with no variation (i.e., all coding values were the same) were removed, and missing data were imputed using an iterative logarithm using the MissMDA package to prevent the results being disturbed by missing values (Husson and Josse 2015). We focus our results on the first two dimensions for each analysis because they were sufficient to explain a high proportion of the variance (minimum 49\%; S4). We demonstrate this approach in detail for the first analysis ecological and economic attributes variables and the fisheries trend outcome (see S5 and S6), and then summarize these for the remaining analyses (see $\mathrm{S} 7$ for full results).

\section{Results}

\subsection{Thematic hypothesis 1- Ecological and economic attributes of the species or ecosystem:}

MPAs were hypothesized to be more successful if the species and ecosystems have high productivity, high ecological resilience and low mobility, in addition to a lower market value, and greater distance to market (Claudet et al. 2010; Collette et al. 2011a; Cinner et al. 2013).

The fisheries trend $(\mathrm{n}=11)$ was correlated to the first dimension $\left(\mathrm{R}^{2} 0.75 ; \mathrm{p}<0.01\right.$; $\mathrm{S} 5$; $\left.\mathrm{S} 6\right)$. This dimension was characterised by the variables: fisheries productivity, economic value, and distance to market and explained $29 \%$ of the data variation. Overall, the first two dimensions explained a total of $50 \%$ of the data variation. Decreasing fishery trends were correlated $(\mathrm{p}<0.01)$ with low fisheries productivity, high resource value, high mobility, and distance to markets (> 
$1000 \mathrm{~km})$ (Table 3). Increasing fisheries trends were correlated $(\mathrm{p}=0.08)$ with intermediate resource value and intermediate fisheries productivity (S7). Declines in wellbeing $(n=10)$ were associated with intermediate fisheries productivity, intermediate resource value $(\mathrm{p}<0.05)$, and close proximity to markets $(\mathrm{p}<0.1)$ (Dimension 1,29\%). No significant relationships were found for ecosystem health outcomes.

The association between trends in fished species, low fisheries productivity, and high economic value is consistent with other findings (Claudet et al. 2010; Collette et al. 2011b). However, the relationship between market distance and fishery declines was unexpected, as many studies indicate that close proximity to markets leads to overexploitation (Liese et al. 2007; Cinner et al. 2013; Table 2). However, in our study, decreased fishery trends were also associated with high value fisheries, including Southern bluefin tuna in the Great Australian Bight Marine Reserve, and Patagonian toothfish in the Heard and Macdonald Islands and Macquarie Island Marine Reserves. Southern bluefin tuna are a highly mobile species, and the population is not very productive (i.e., they are long lived and late maturing), with population estimates at $9 \%$ of the initial spawning stock biomass (Commission for the Conservation of Southern Bluefin Tuna 2014). Southern bluefin tuna are targeted in the Great Australian Bight where they are caught using purse seines and subsequently placed in ranches before being sold to Japanese markets. Despite their stock declines they remain the most valuable fishery in South Australia (Skirtun et al. 2013). Similarly, Patagonian toothfish that also have low productivity are targeted around the Subantarctic Heard and Macdonald Islands and Macquarie Island. Despite difficult fishing conditions and vast distances to market, the high value of the Patagonian toothfish means that fishing in these remote areas can be commercially profitable. The Patagonian toothfish stocks in 
these areas have been exploited since the mid-1990s, and although the biomass has decreased, estimates suggest that they remain at healthy levels (i.e., $>50 \%$ of unfished levels).

The correlation between increasing fisheries trends and resources with intermediate levels of productivity and value is likely driven by the incentives that actors face to manage these types of resources (Basurto and Ostrom 2009; Ostrom 2009b). Fisheries with a sufficiently high value and productivity generate incentives for actors to invest in management (e.g., gear restrictions and/or no take zones (Basurto and Ostrom 2009; Ostrom 2009b)), but not so high as to promote unsustainable rates of exploitation. However, the same attributes were also correlated with a decline in wellbeing, reflecting a possible trade-off between effective management of fisheries and associated wellbeing in LMPAs. For example, within the time period we investigated, in the Great Barrier Reef Marine Park, a decline in wellbeing occurred as a result of the extensive establishment of no-take areas (33\% of the MPA) that reduced the availability of fishing grounds to fishers (Ban et al. 2015), but has also seen an increase in fish biomass (Emslie et al. 2015).

Table 1. Summary of LMPAs included in this study, with their associated ecological and wellbeing trends (outcomes) for both the fishery and ecosystem health proxies. Trends were assessed over a stable governance time period (S3). Up arrows indicate improvements in wellbeing or conditions of fisheries and ecosystem health indicator, down arrows indicate declines, and dashes indicate that outcomes have remained stable or have mixed results. The coloured boxes for fishery and ecosystem health trends reflect the state of the resource, and broadly reflect 'stable states': green boxes indicate an ecosystem or species in good condition, orange boxes indicate potential proximity to a threshold, red boxes indicate a degraded or 
overexploited condition. The state was not available for wellbeing. The state was not included in the analysis, but is noted here for information only. NA denotes not applicable, and $\mathrm{x}$ means no information available. Level of documentation was judged on a three-point scale and was based on the number of Google scholar results for each case (low $<1,000$; medium 1,001-9,999; high $>10,000)$.

\begin{tabular}{|c|c|c|c|c|}
\hline Case & 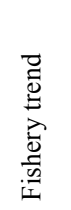 & 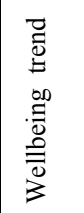 & 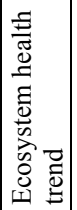 & 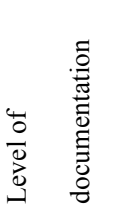 \\
\hline Cenderawasih Bay National Park (Indonesia) & $\square$ & & $\square$ & Low \\
\hline Central California National Marine Sanctuaries (USA) & 1 & & 1 & High \\
\hline Galapagos Marine Reserve (Ecuador) & 5 & & $\square$ & High \\
\hline Great Australian Bight Marine Park (Australia) & 4 & & 4 & Medium \\
\hline Great Barrier Reef Marine Park (Australia) & 1 & & 5 & High \\
\hline Heard Island and McDonald Islands (Australia) & 5 & & $\square$ & Medium \\
\hline Macquarie Island Marine Reserve (Australia) & 5 & & 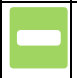 & Medium \\
\hline Papahānaumokuākea Marine National Monument (USA) & 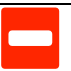 & NA & $\square$ & High \\
\hline Raja Ampat MPA network (Indonesia) & $\square$ & & $\infty$ & Medium \\
\hline Seaflower MPA (Colombia) & (5) & $\mathrm{x}$ & 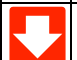 & Low \\
\hline Svalbard Nature Reserves (Norway) & 1 & & 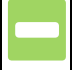 & Medium \\
\hline Wakatobi National Park (Indonesia) & ـ & 1 & $\infty$ & Medium \\
\hline
\end{tabular}


Table 2. Hypotheses with the associated variables and their expected impact on trends and wellbeing, and the corresponding support found in our study for the fisheries and ecosystem health interactions (for additional detail on findings please refer to Table 3)

$\checkmark$ = evidence found, $\bigcirc$ = unexpected finding: result was either not linked to a hypothesis or counter-intuitive to the hypothesis.

\begin{tabular}{|c|c|c|c|c|c|c|c|}
\hline 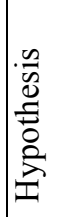 & Variable category & $\begin{array}{c}\text { Expected } \\
\text { fisheries } \\
\text { trend }\end{array}$ & Evidence & $\begin{array}{c}\text { Expected } \\
\text { wellbeing } \\
\text { trend }\end{array}$ & Evidence & $\begin{array}{l}\text { Expected } \\
\text { ecosystem } \\
\text { health trend }\end{array}$ & Evidence \\
\hline \multirow{5}{*}{1} & Low productivity & 5 & $\checkmark$ & & $\mathrm{O}$ & & \\
\hline & High ecological resilience & t & & & O & 1 & \\
\hline & High mobility of the commons & $\nabla$ & $\checkmark$ & & & & \\
\hline & High market value & $\nabla$ & $\checkmark$ & & O & & \\
\hline & Close proximity to market & 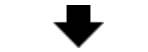 & O & & & 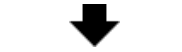 & \\
\hline \multirow{6}{*}{2} & $\begin{array}{c}\text { High compliance and } \\
\text { enforcement }\end{array}$ & & $y$ & & & & \\
\hline & Older MPA & 1 & $\checkmark$ & & & & \\
\hline & Larger spatial extent & & & & & & \\
\hline & Larger proportion no-take areas & 1 & & & & & \\
\hline & Greater isolation & 1 & & & & & \\
\hline & $\begin{array}{c}\text { Explicit inclusion of MPA } \\
\text { design criteria }\end{array}$ & & & & & & \\
\hline \multirow[t]{2}{*}{3} & $\begin{array}{c}\text { Clear boundaries between users } \\
\text { and non-users }\end{array}$ & & & & & & D \\
\hline & Clear resource boundaries & 1 & & 1 & & & $\mathrm{O}$ \\
\hline
\end{tabular}




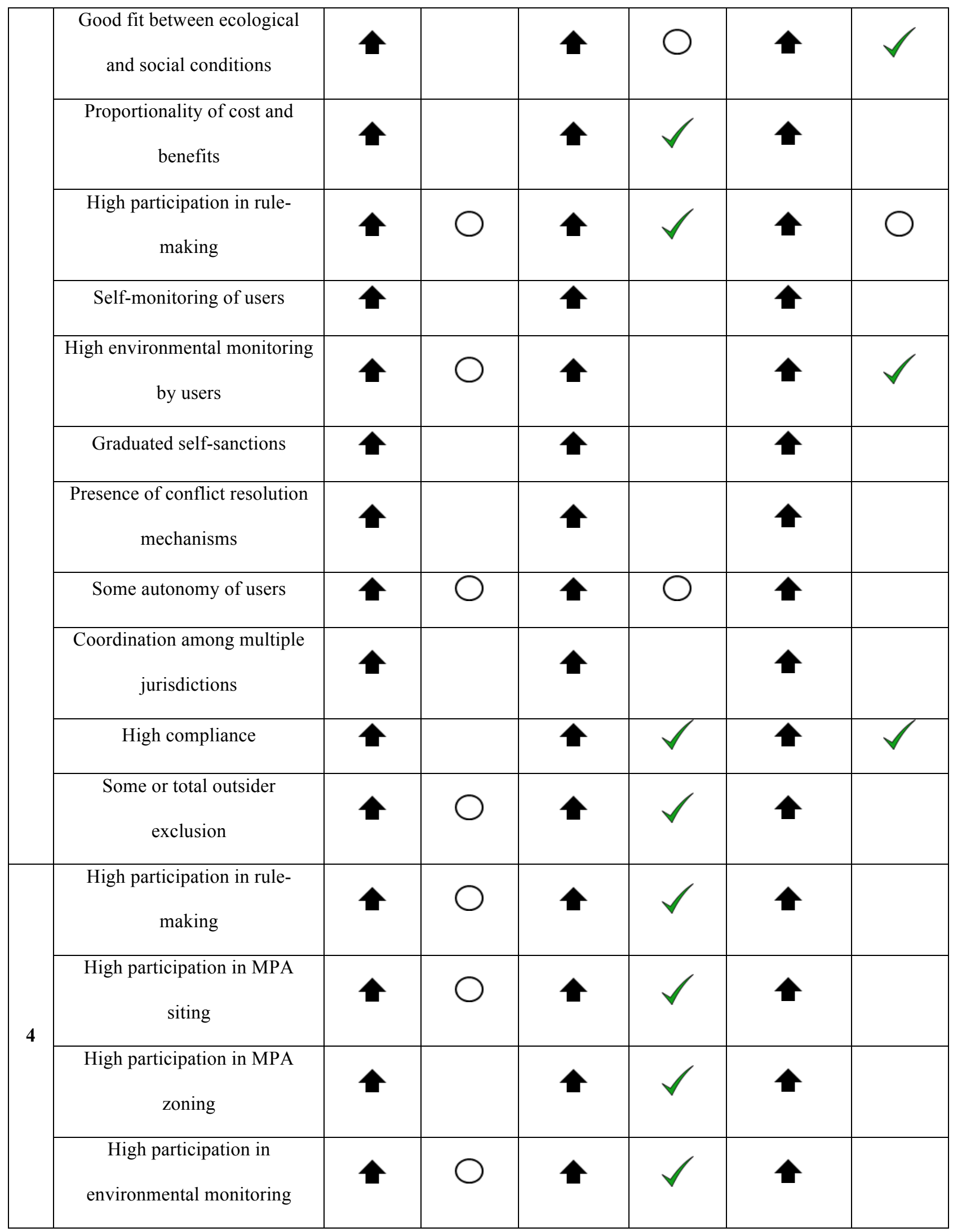




\begin{tabular}{|c|c|c|c|c|c|c|c|}
\hline $\begin{array}{c}\text { High participation in social } \\
\text { monitoring }\end{array}$ & $\boldsymbol{\Delta}$ & & $\boldsymbol{1}$ & $\boldsymbol{\gamma}$ & 人 & \\
\hline
\end{tabular}

3.2 Thematic hypothesis 2 - Attributes of the MPA: MPAs that are older, have a larger spatial extent, larger proportion of no-take areas, more isolation, high levels of compliance and enforcement (Edgar et al. 2014), in addition to explicit inclusion of MPA design criteria (comprehensive, adequate, representative) in MPA selection and zoning were hypothesized to result in more successful outcomes (Margules and Pressey 2000).

The fisheries trend $(n=12)$ was correlated with the second dimension $\left(\mathrm{R}^{2} 0.73 ; \mathrm{p}<0.01\right)$; which was characterised by the variables: age since designation, duration of current governance regime (snapshot), and enforcement; this dimension explained $25 \%$ of the data variation. Improved fisheries trends were associated with older MPAs and higher levels of compliance and enforcement (Table 3). No significant associations were found for other outcomes.

Although our study differed from Edgar et al. (2014), which was based on an examination of MPAs globally $(\mathrm{n}=87)$ and used measures of fish biomass across sites as metrics of effectiveness, we also found older MPAs and higher levels of compliance and enforcement to be associated with positive fisheries trends. Enforcement has been discussed as crucial for achieving conservation goals in LMPAs, which our data supports. The age of the MPA could be important because it provides time for species to recover (Lester et al. 2009), for trust to develop among actors (Ostrom 2009a), and for management to be adapted and improved (Armitage et al. 2008). For instance, the adaptive management approach used to govern the Great Barrier Reef Marine 
Park is the result of approximately 40 years of investments in conservation and opportunities for stakeholders to gain knowledge and experience with management and enforcement (McCook et al. 2010). In particular, long-term ecological monitoring and environmental research has provided knowledge to support the development of more effective zoning and fisheries management regimes for improved fisheries outcomes (Harrison et al. 2012). Similarly, in the central California National Marine Sanctuaries, the Gulf of the Farallones has 35 years of monitoring and enforcement experience that has allowed managers and scientists to improve planning, engage with complementary resource agencies (i.e., the National Marine Fisheries Service), create informed spatial plans for essential fish habitats and adaptive rockfish conservation areas, and to observe recovery (de Marignac et al. 2009).

\subsection{Thematic hypothesis 3 - social and governance attributes: the institutional design}

principles: We examined the institutional design principles from the literature on common pool resources (Ostrom 1990; Cox et al. 2010). We hypothesized that presence of the institutional design principles would lead to more successful outcomes.

The fisheries trend $(n=11)$ was correlated to the second dimension $\left(R^{2} 0.73 ; p<0.01\right)$, which explained $24 \%$ of the data variation. A declining fisheries trend $(p=0.003)$ was correlated with moderate external recognition, intermediate levels of participation and environmental monitoring, and total outsider exclusion $(\mathrm{p}<0.05)$, no self-monitoring or sanctions, intermediate social-ecological fit, and proportionality of cost and benefits $(\mathrm{p}<0.1)$. 
Improvements $(\mathrm{p}=0.07)$ and declines $(\mathrm{p}=0.08)$ in the wellbeing of fishery user groups $(\mathrm{n}=10)$ were correlated with the second dimension, which explained $25 \%$ of the data variability. Improved wellbeing was associated with the variable categories: high compliance, proportionality of cost and benefits, intermediate social-ecological fit $(\mathrm{p}<0.05)$, rigid boundaries, moderate external recognition, and intermediate environmental monitoring $(p<0.10)$. A decline in wellbeing was associated with the variable categories: some compliance, no proportionality of cost and benefits, low participation, low external recognition, no outsider exclusion $(p<0.05)$, low social-ecological fit, and low environmental monitoring $(\mathrm{p}<0.10)$.

Improved ecosystem health trends $(n=10)$ were associated with the first dimension, which explained $27 \%$ of the data variation, and were correlated with the variable categories: high environmental monitoring, high social-ecological fit, intermediate participation, moderate boundary negotiability, unclear user boundaries, high compliance $(\mathrm{p}<0.05)$, and fuzzy user boundaries $(\mathrm{p}<0.10$; Table 3$)$.

While the presence of the institutional design principles is commonly thought to lead to improved trends in resource conditions, we found outsider exclusion plus the partial presence (intermediate or moderate values) of three of the institutional design principles to be associated with a declining fisheries trend. Given the theoretical mechanisms by which such principles can work to enable sustainable commons management, these are surprising results that warrant unpacking, particularly with respect to the principle of outsider exclusion. Three of the Australian LMPAs experienced declining fisheries yet had intermediate levels of participation in management and were active participants in environmental monitoring programs such as tag- 
recapture surveys. Southern bluefin tuna are fished in the Great Australian Bight Marine Park, but have also been intensively fished throughout their range since the 1950s and have experienced severe population declines (Commission for the Conservation of Southern Bluefin Tuna 2014). In contrast, the declines in Patagonian toothfish in the Australian Sub-Antarctic LMPAs (Heard and Macdonald Islands, and Macquarie Island) are an intentional management action: relatively recently exploited stocks that are considered above Maximum Sustainable Yield. Outsider exclusion is postulated to be an important factor to ensure that a commons is not over-exploited (Ostrom 1990; Basurto and Ostrom 2009; Cox et al. 2010). However, the effects of exclusion might also depend upon the extent to which actors are dependent upon a particular stock. The same companies hold rights to fish for toothfish in both the Heard and MacDonald Islands and Macquarie Islands fisheries (and other areas) and as a result have lower incentives to lobby for conservation of any individual stock. Similarly because of the high economic value of the fished species (Southern bluefin tuna and Patagonian toothfish); short-term harvests might be rationally preferred over long-term conservation (and see thematic hypothesis 1). More generally, it appears that the presence of individual factors is neither necessary nor sufficient for success, highlighting the limitations of institutional theory when applied to complex cases.

Improved wellbeing related to fisheries was associated with more equitable distribution of social impacts and a system where rules are adjusted to fit local conditions (e.g., proportionality of costs and benefits, intermediate social-ecological fit, intermediate external recognition). Where the benefits of managing resources are distributed in proportion to the costs that actors incur in managing them, actors are more likely to make long-term investments of time and resources in activities such as monitoring and rule-making (Cox et al. 2010); providing benefits to the group 
as a whole. Conversely, a decline in wellbeing was linked to the absence of many of these conditions including a lack of proportionality of cost and benefits, low participation, and low external recognition: suggesting a situation where there is a lack of recognition and rights in LMPA governance, the rules do not necessarily reflect local conditions or needs, and the fishers are bearing costs of management actions (e.g., no-take zones). In the Wakatobi National Park (WNP), the Bajau depend almost exclusively on marine resources and fishing is central to their culture and society (Clifton 2013). The governance of the WNP is poorly adapted to local institutions and marine system dynamics (von Heland and Clifton 2014) and the Bajau have had limited involvement in the rules of the park and ongoing environmental monitoring. Bajau have been marginalised through both state and NGO initiatives in the WNP (Clifton 2013) and their wellbeing can be considered to have declined, with reported changes in social customs and perceived loss in freedom, which are elements central to their identity (C.Tam, pers comm). Conversely, another LMPA in Indonesia is the Raja Ampat marine network that was established 11 years after the WNP through a bottom-up approach. This network has a higher percentage of no-take zones than WNP and each of the MPAs in the LMPA network are managed collaboratively between local communities, NGOs, and government (intermediate socialecological fit, and proportionality). Consequently there is high compliance, and improvements have been noted across a range of wellbeing indicators (Glew et al. 2015).

An improved trend in ecosystem health was also linked to the factors that suggest the rules are appropriate for local conditions and needs, with involvement of groups with environmental monitoring and high compliance. This configuration is illustrated with the Central California National Marine Sanctuaries (CCNMS). The CCNMS maintains high levels of ecosystem health 
(Office of National Marine Sanctuaries 2008) and has also successfully mitigated threats to ecosystem health in recent years (e.g., oil exploitation) (Office of National Marine Sanctuaries 2010). Within the CCNMS there are a number of user-led long-term monitoring projects, and the Sanctuary Advisory Council formally incorporates stakeholder input into the management of the LMPA, and compliance is high. While the user boundaries are unclear, this reflects the flexibility and inclusivity of the rule system to incorporate any potential user, which in this instance does not appear to adversely affect trends in ecosystem health.

\subsection{Thematic hypothesis 4 -social attributes of the MPA: Participation: Participation is} commonly linked to successful resource management in the literature on common pool resources. However, the design principles are limited by using a single aggregate indicator of participation; neglecting the multiple aspects of participation that are potentially relevant for LMPAs. We hypothesized that LMPAs are more successful when there is participation at all stages in rule-making; including MPA siting, MPA zoning, as well as environmental and social monitoring.

The fisheries trend $(\mathrm{n}=11)$ was correlated to the second dimension $\left(\mathrm{R}^{2} 0.59 ; \mathrm{p}=0.03\right)$, characterised by the participation variables: rule-making, zoning, environmental monitoring, and siting, and explained $31 \%$ of the data variation. A declining fisheries trend $(\mathrm{p}=0.01)$ was associated with intermediate levels of participation in environmental monitoring, siting, rulemaking, and zoning (Table 3). Improvements in user wellbeing $(\mathrm{n}=10)$ were correlated to the first dimension ( $\mathrm{p}=0.05)$, and associated with high participation in zoning, social monitoring, 
siting, rule-making, and environmental monitoring ( $<<0.05$; Table 3$)$. No significant associations were found for other outcomes.

Intermediate levels of participation in different activities were associated with declines in fished species, whereas high levels of participation were linked to improved wellbeing. The Raja Ampat Marine Network illustrates the importance of participation, as it has high levels of participation in all aspects, and is unique among our sample of LMPAs in that it was initiated and established through a collaborative effort between communities, government, and International NGOs. Local communities originally designated the sites through customary law (adat declarations), building on local marine tenure and traditional management, and they remain formally involved in the management of the MPAs. A variety of wellbeing indicators including food security and school enrollment, have been recorded as improving across the sites (Glew et al. 2015). By contrast, the sea cucumber fishery in Galapagos Marine Reserve has experienced dramatic declines, and is now considered overexploited and economically extinct (Toral-Granda 2008). The Galapagos Marine Reserve had intermediate levels of participation because it has a two-tier governance framework, including the Participatory Management Board, a decision making body comprised of local representatives of tourism, naturalist guide, and fishing sectors, Galapagos National Parks Service, and (until 2008) the Charles Darwin Foundation. Although the creation of the Participatory Management Board was a milestone in community participation, the first five years were dominated by social unrest and conflict (Jones 2013). During this time, the Participatory Management Board established sea cucumber quotas that were based on political considerations rather than scientific data, which contributed to the overexploitation of sea cucumbers (Wolff et al. 2012). However, in more recent years, the Participatory 
Management Board has been able to reach consensus, and the sea cucumber fishery which was closed for four years (it was opened in 2015), although it has not yet shown signs of recovery.

Table 3. Summary of the variable categories correlated with outcomes $(p<0.05)$ for each thematic hypothesis. Green text = associated with improved outcome; red text $=$ associated with decline. Where no correlations to outcomes were found, the cell has been shaded grey.

\begin{tabular}{|c|c|c|c|}
\hline & \multicolumn{3}{|c|}{ Outcomes } \\
\hline & Fisheries & Wellbeing & Ecosystem health \\
\hline $\begin{array}{l}\text { 1. Ecological \& } \\
\text { economic attributes }\end{array}$ & $\begin{array}{l}\text { Low productivity; } \\
\text { High economic value; } \\
\text { Distance to market > } 1000 \mathrm{~km} \text {; } \\
\text { High mobility }\end{array}$ & $\begin{array}{l}\text { Intermediate productivity; } \\
\text { Intermediate economic value }\end{array}$ & \\
\hline $\begin{array}{l}\text { 2. Attributes of } \\
\text { MPAs }\end{array}$ & $\begin{array}{l}\text { Older; } \\
\text { High enforcement }\end{array}$ & & \\
\hline $\begin{array}{l}\text { 3. Design } \\
\text { principles }\end{array}$ & $\begin{array}{l}\text { Moderate external recognition; } \\
\text { Intermediate participation; } \\
\text { Intermediate environmental } \\
\text { monitoring; } \\
\text { Total outsider exclusion }\end{array}$ & $\begin{array}{l}\text { High compliance; } \\
\text { Proportionality of cost \& benefits; } \\
\text { Intermediate social-ecological fit } \\
\text { Some compliance; } \\
\text { No proportionality of cost \& benefits; } \\
\text { Low participation; } \\
\text { Low external recognition; } \\
\text { No outsider exclusion }\end{array}$ & $\begin{array}{l}\text { High environmental } \\
\text { monitoring; } \\
\text { High social-ecological fit; } \\
\text { Intermediate participation; } \\
\text { Moderate boundary } \\
\text { negotiability; } \\
\text { Unclear user boundaries; } \\
\text { High compliance }\end{array}$ \\
\hline 4. Participation & $\begin{array}{l}\text { Intermediate participation in: } \\
\text { siting; } \\
\text { rulemaking; } \\
\text { environmental monitoring }\end{array}$ & $\begin{array}{l}\text { High participation in: } \\
\text { zoning; } \\
\text { social monitoring; } \\
\text { siting; rulemaking; environmental } \\
\text { monitoring }\end{array}$ & \\
\hline
\end{tabular}

\section{Discussion and Conclusions}


Marine protected areas (MPAs) remain an important tool for biodiversity conservation and there has been an increase in the implementation of LMPAs (Spalding et al. 2013; Boonzaier and Pauly 2016). Our study is the first to examine the extent to which findings from small-scale MPAs and common pool resource theory apply to LMPAs. We found that: (i) targeted species with low levels of productivity, high mobility, and high market value were related to fisheries decline; (ii) older MPAs with higher levels of compliance and enforcement were associated with improved fisheries trends; (iii) low levels of participation by resource users and limited external recognition were related to declines in wellbeing, whereas (iv) high participation in zoning, social monitoring, siting, rulemaking and environmental monitoring were associated with improvements in wellbeing (Table 3).

There were also a number of unexpected results. For instance, we expected to observe improvements in fished species with an increasing distance to market, but rather found the opposite relationship. Similarly, the association between declining fisheries and intermediate levels of external recognition, participation, and high levels of outsider exclusion are somewhat at odds with Ostrom's (1990) institutional design principles. We also expected intermediate or high (as opposed to low) levels of participation in siting, rulemaking, and environmental monitoring to be associated with improvements in targeted fish stocks. We assessed the thematic hypotheses against trends in fisheries, ecosystem health, and wellbeing, whereas many studies from which the theory is derived have used static outcome measures (e.g., relative biomass, subjective assessments of environmental conditions, state of the system, etc.). Trends provide a different way of thinking about effectiveness than state (e.g., has governance halted or reversed declining trends?). Additionally, there are many challenges to scaling up theory from the small- 
scale to large-scale systems, and indeed the applicability of the design principles to large-scale environmental governance has been questioned (Young 2002; Araral 2014). Although our results provide partial support for the design principles at the large-scale, they also reveal some of the limitations of institutional theory when applied to complex cases.

Stakeholder participation is now synonymous with protected area design and environmental management more broadly for both instrumental (better outcomes) and ethical reasons (people should be involved in decisions that affect them) (Berkes 2009). Indeed, we found improvements in wellbeing associated with high participation in zoning, social monitoring, siting, rule-making, and environmental monitoring. At smaller scales, although many groups may have a stake in management decisions, it is far easier to identify who those stakeholders are and develop mechanisms to mitigate impacts from MPAs. Furthermore, transaction costs associated with participation are likely to rise precipitously at larger scales particularly for tasks such as enforcement and environmental monitoring. For these reasons, designing (and indeed coding) governance arrangements based on the autonomy and participation of resource users are challenging at large-scales. Many LMPAs have invested considerable effort in designing processes for stakeholder engagement, and yet, given the size of LMPAs, these initiatives only reach a subset of stakeholders. Moreover, stakeholder groups often struggle to achieve broadscale representation of their members in response to LMPAs because of the challenge in organizing and mobilizing a large group with typically diverse interests, values, and perspectives (Wilhelm et al. 2014). In large-scale systems it is therefore relatively rare to achieve high levels of citizen control or user participation in management. Importantly, our data suggest that even in 
the absence of improving fisheries, high levels of participation and proportionality of costs and benefits among stakeholders contributes to improvements in the wellbeing of user groups.

Our analysis of LMPAs is limited by a number of factors. First, the small number of LMPAs with at least 5 years of active management limits our ability to detect statistically significant relationships (although we note that this was the full sample of cases available; S1). Furthermore, where cases did not have a direct user of fishery resources (Papahānaumokuākea, which is all notake and far from human populations) or information available on wellbeing trends (Seaflower) they were excluded from certain analyses, which further eroded statistical power of some tests. Even though all of the LMPAs in our sample have been actively managed for at least five years, long-term data were not always readily available. Studies were also biased towards the ecological aspects of the MPA, with lower levels of documentation for social data. In addition, there is a known publication bias of 'positive' studies and it is likely that negative impacts or outcomes from LMPAs are under-reported due to concerns about exposing shortcomings. We encourage improved monitoring and reporting from LMPAs to enable cross-fertilization of lessons across the growing population of LMPAs, including failures and successes. Finally, global meta-analyses are inherently challenged by the variability of cases and different metrics across variables. We overcame this limitation by measuring variables with 3-point Likert scales and binary variables (S2), but this approach masks more nuanced information for cases where more detail exists. Despite these limitations, our study demonstrates a first attempt at investigating the applicability of hypotheses developed from small-scale systems for LMPAs that can be used for the design of future studies and the collection of comparable data in multiple LMPAs. 
Our findings allow us to provide some general guidance for LMPA management. First, compliance and enforcement matters across multiple outcomes: increased trends in ecosystem health and fished stocks, and improved wellbeing. Thus improving compliance and enforcement should be a priority for managers of LMPAs, and should be considered in their design and implementation. Second, participation appears to influence various outcomes, with intermediate levels of participation being linked to declines in fished species but improvements in ecosystem health, and high participation being associated with improvements in wellbeing. Engaging in meaningful participation in all aspects of design, implementation, and management of LMPAs should be a priority for managers. Finally, some attributes of MPAs and species also matter, and thus management activities should consider the productivity, mobility, and economic value of targeted species. Some of these variables can be directly influenced by the design and management of LMPAs (e.g., compliance and enforcement, participation), whereas others (e.g., productivity, mobility, market value) are outside of the influence of managers.

While some of our findings can lead to general recommendations, there are unlikely to be failsafe panaceas for creating socially and ecologically effective LMPAs. Rather, it is important to craft management to fit the local context (Young 2002). Our MPA cases may have had positive outcomes for a diversity of reasons that are tied to the diversity of the ecological environment, the actors, or the governance system itself. Improved monitoring and reporting of a range of social and ecological outcomes will aid further understanding of factors of success in LMPAs. 


\section{References}

Araral, E. 2014. Ostrom, Hardin and the commons: A critical appreciation and a revisionist view. Environmental Science \& Policy, 36, 11-23.

Armitage, D.R., Plummer, R., Berkes, F., Arthur, R.I., Charles, A.T., Davidson-Hunt, I.J., Diduck, A.P., Doubleday, N.C., Johnson, D.S. \& Marschke, M. 2008. Adaptive comanagement for social-ecological complexity. Frontiers in Ecology and the Environment, 7, 95-102.

Ban, N.C., Evans, L.S., Nenadovic, M. \& Schoon, M. 2015. Interplay of multiple goods, ecosystem services, and property rights in large social-ecological marine protected areas. Ecology and Society, 20, 2.

Basurto, X. \& Ostrom, E. 2009. Beyond the Tragedy of the Commons. Economia delle fonti di energia e dell'ambiente, 26, 35-60.

Berkes, F. 2009. Evolution of co-management: Role of knowledge generation, bridging organizations and social learning. Journal of Environmental Management, 90, 16921702.

Boonzaier, L. \& Pauly, D. 2016. Marine protection targets: an updated assessment of global progress. Oryx, 50, 27-35.

Cheung, W., Lam, V., Sarmiento, J., Kearney, K., Watson, R. \& Pauly, D. 2009. Projecting global marine biodiversity impacts under climate change scenarios. Fish and Fisheries, 10, 235-251.

Cinner, J.E., Graham, N.A.J., Huchery, C. \& Macneil, M.A. 2013. Global Effects of Local Human Population Density and Distance to Markets on the Condition of Coral Reef Fisheries. Conservation Biology, 27, 453-458.

Claudet, J., Osenberg, C., Domenici, P., Badalamenti, F., Milazzo, M., Falcón, J., Bertocci, I., Benedetti-Cecchi, L., García-Charton, J. \& Goñi, R. 2010. Marine reserves: fish life history and ecological traits matter. Ecological Applications, 20, 830-839.

Clifton, J. 2013. Refocusing conservation through a cultural lens: Improving governance in the Wakatobi National Park, Indonesia. Marine Policy, 41, 80-86.

Collette, B., Carpenter, K., Polidoro, B., Juan-Jordá, M., Boustany, A., Die, D., Elfes, C., Fox, W., Graves, J. \& Harrison, L. 2011a. High value and long life-double jeopardy for tunas and billfishes. Science, 333, 291-292.

Collette, B.B., Carpenter, K.E., Polidoro, B.A., Juan-Jordá, M.J., Boustany, A., Die, D.J., Elfes, C., Fox, W., Graves, J., Harrison, L.R., McManus, R., Minte-Vera, C.V., Nelson, R., Restrepo, V., Schratwieser, J., Sun, C.-L., Amorim, A., Brick Peres, M., Canales, C., Cardenas, G., Chang, S.-K., Chiang, W.-C., de Oliveira Leite, N., Harwell, H., Lessa, R., Fredou, F.L., Oxenford, H.A., Serra, R., Shao, K.-T., Sumaila, R., Wang, S.-P., Watson, R. \& Yáñez, E. 2011b. High Value and Long Life-Double Jeopardy for Tunas and Billfishes. Science, 333, 291-292.

Commission for the Conservation of Southern Bluefin Tuna 2014. Report of the Nineteenth Meeting of the Scientific Committee. Auckland, New Zealand.

Convention on Biological Diversity. 2010. Aichi Biodiversity Targets [Online]. http://www.cbd.int/sp/targets/: Convention on Viological Diversity. [Accessed 3 December 2013 2013].

Cox, M. 2014. Understanding large social-ecological systems: introducing the SESMAD project. International Journal of the Commons, 8, 265-276. 
Cox, M., Arnold, G. \& Villamayor Tomás, S. 2010. A review of design principles for community-based natural resource management. Ecology and Society, 15, 38.

Cox, M., Villamayor-Tomas, S., Epstein, G., Evans, L., Ban, N.C., Fleischman, F., Nenadovic, M. \& Garcia-Lopez, G. 2016. Synthesizing theories of natural resource management and governance. Global Environmental Change, 39, 45-56.

Day, J., Dudley, N., Hockings, M., Holmes, G., Laffoley, D., Stolton, S. \& Wells, S. 2012. Guidelines for applying the IUCN Protected Area Management Categories to Marine Protected Areas. Gland, Switzerland: IUCN.

de Marignac, J., Hyland, J., Lindholm, J., DeVogelaere, A., Balthis, W.L. \& Kline, D. 2009. A comparison of seafloor habitats and associated benthic fauna in areas open and closed to bottom trawling along the central California Continental Shelf. Marine Sanctuaries Conservation Series. Silver Spring, MD: NOAA/National Ocean Service/Office of National Marine Sanctuaries.

Devillers, R., Pressey, R.L., Grech, A., Kittinger, J.N., Edgar, G.J., Ward, T. \& Watson, R. 2015. Reinventing residual reserves in the sea: are we favouring ease of establishment over need for protection? Aquatic Conservation: Marine and Freshwater Ecosystems, 25, 480504.

Edgar, G.J., Stuart-Smith, R.D., Willis, T.J., Kininmonth, S., Baker, S.C., Banks, S., Barrett, N.S., Becerro, M.A., Bernard, A.T.F., Berkhout, J., Buxton, C.D., Campbell, S.J., Cooper, A.T., Davey, M., Edgar, S.C., Forsterra, G., Galvan, D.E., Irigoyen, A.J., Kushner, D.J., Moura, R., Parnell, P.E., Shears, N.T., Soler, G., Strain, E.M.A. \& Thomson, R.J. 2014. Global conservation outcomes depend on marine protected areas with five key features. Nature, 506, 216-220.

Emslie, M.J., Logan, M., Williamson, D.H., Ayling, A.M., MacNeil, M.A., Ceccarelli, D., Cheal, A.J., Evans, R.D., Johns, K.A. \& Jonker, M.J. 2015. Expectations and outcomes of reserve network performance following re-zoning of the Great Barrier Reef Marine Park. Current Biology, 25, 983-992.

Ferse, S.C., Costa, M.M., Máñez, K.S., Adhuri, D.S. \& Glaser, M. 2010. Allies, not aliens: increasing the role of local communities in marine protected area implementation. Environmental Conservation, 37, 23-34.

Glew, L., Ahmadia, G.N., Fox, H.E., Mascia, M.B., Mohebalian, P. \& Pakiding, F. 2015. State of the Bird's Head Seascape MPA Network Report 2015. Washington D.C., United States, Jakarta, Indonesia, and Manokwari, Indonesia.: World Wildlife Fund, Conservation International, Rare, The Nature Conservancy, and Universitas Papua, .

Gruby, R.L., Gray, N.J., Campbell, L.M. \& Acton, L. 2016. Toward a Social Science Research Agenda for Large Marine Protected Areas. Conservation Letters, 9, 153-163.

Halpern, B.S. \& Warner, R.R. 2002. Marine reserves have rapid and lasting effects. Ecology Letters, 5, 361-366.

Harrison, H.B., Williamson, D.H., Evans, R.D., Almany, G.R., Thorrold, S.R., Russ, G.R., Feldheim, K.A., Van Herwerden, L., Planes, S., Srinivasan, M. \& Berumen, M.L. 2012. Larval export from marine reserves and the recruitment benefit for fish and fisheries. Current Biology, 11, 1023-1028.

Husson, F. \& Josse, J. 2015. missMDA: Handling Missing Values with Multivariate Data Analysis. R package version 1.8.2.

Husson, F., Josse, J., Lê, S. \& Mazet, J. 2015. FactoMineR: Multivariate Exploratory Data Analysis and Data Mining. R package version 1.31.4. 
Husson, F., Lê, S. \& Pagès, J. 2010. Exploratory multivariate analysis by example using $R$, CRC press.

Johannes, R.E. 2002. The renaissance of community-based marine resource management in Oceania. Annual Review of Ecology and Systematics, 33, 317-340.

Jones, P.J. 2013. A governance analysis of the Galápagos Marine Reserve. Marine Policy, 41, $65-71$.

Lê, S., Josse, J. \& Husson, F. 2008. FactoMineR: an R package for multivariate analysis. Journal of statistical software, 25, 1-18.

Lester, S.E., Halpern, B.S., Grorud-Colvert, K., Lubchenco, J., Ruttenberg, B.I., Gaines, S.D., Airamé, S. \& Warner, R.R. 2009. Biological effects within no-take marine reserves: a global synthesis. Marine Ecology Progress Series, 384, 33-46.

Liese, C., Smith, M.D. \& Kramer, R.A. 2007. Open access in a spatially delineated artisanal fishery: the case of Minahasa, Indonesia. Environment and Development Economics, 12, 123.

Margules, C.R. \& Pressey, R.L. 2000. Systematic conservation planning. Nature, 405, 243-253.

Marine Conservation Institute. 2015. MPAtlas [Online]. Seattle, WA, United States. Available: www.mpatlas.org 2015].

Maxwell, S.M., Ban, N.C. \& Morgan, L.E. 2014. Pragmatic approaches for effective pelagic marine protected area management. Endangered Species Research, 26, 59-74.

Maxwell, S.M. \& Morgan, L.E. 2013. Facilitated foraging of seabirds on pelagic fishes: implications for management of pelagic marine protected areas. Marine Ecology Progress Series, 481, 289-303.

McCay, B.J. \& Jentoft, S. 1996. From the bottom up: participatory issues in fisheries management. Society \& Natural Resources, 9, 237-250.

McCook, L.J., Ayling, T., Cappo, M., Choat, J.H., Evans, R.D., De Freitas, D.M., Heupel, M., Hughes, T.P., Jones, G.P. \& Mapstone, B. 2010. Adaptive management of the Great Barrier Reef: A globally significant demonstration of the benefits of networks of marine reserves. Proceedings of the National Academy of Sciences, 107, 18278-18285.

McLeod, E., Salm, R., Green, A. \& Almany, J. 2009. Designing marine protected area networks to address the impacts of climate change. Frontiers in Ecology and the Environment, 7, 362-370.

Office of National Marine Sanctuaries 2008. Monterey Bay National Marine Sanctuary Final Management Plan. . Prepared as part of the joint management plan review (JMPR) Volume III of IV. . Monterey, CA U.S. Department of Commerce, National Oceanic and Atmospheric Administration, Office of National Marine Sanctuaries, .

Office of National Marine Sanctuaries 2010. Gulf of the Farallones National Marine Sanctuary Condition Report 2010. Silver Spring, MD.: U.S. Department of Commerce, National Oceanic and Atmospheric Administration, Office of National Marine Sanctuaries,.

Ostrom, E. 1990. Governing the commons: The evolution of institutions for collective action, Cambridge, UK, Cambridge University Press.

Ostrom, E. 2009a. Building Trust to Solve Commons Dilemmas: Taking Small Steps to Test an Evolving Theory of Collective Action. In: Levin, S.A. (ed.) Games, Groups, and the Global Good. Berlin Heidelberg: Springer.

Ostrom, E. 2009b. A general framework for analyzing sustainability of social-ecological systems. Science, 325, 419-422. 
R Core Team 2015. R: A language and environment for statistical computing. 3.2.2 ed. Vienna, Austria: R Foundation for Statistical Computing.

Sheppard, C.R., Ateweberhan, M., Bowen, B., Carr, P., Chen, C.A., Clubbe, C., Craig, M., Ebinghaus, R., Eble, J. \& Fitzsimmons, N. 2012. Reefs and islands of the Chagos Archipelago, Indian Ocean: why it is the world's largest no-take marine protected area. Aquatic Conservation: Marine and Freshwater Ecosystems, 22, 232-261.

Skirtun, M., Sahlqvist, P. \& Vieira, S. 2013. Australian fisheries statistics 2012. FRDC project 2010/208. Canberra, Australia: ABARES.

Spalding, M.D., Meliane, I., Milam, A., Fitzgerald, C. \& Hale, L.Z. 2013. Protecting Marine Spaces: global targets and changing approaches. Ocean Yearbook, 27.

Toonen, R.J., Andrews, K.R., Baums, I.B., Bird, C.E., Concepcion, G.T., Daly-Engel, T.S., Eble, J.A., Faucci, A., Gaither, M.R. \& Iacchei, M. 2011. Defining boundaries for ecosystembased management: a multispecies case study of marine connectivity across the Hawaiian Archipelago. Journal of Marine Biology, 2011.

Toonen, R.J., Wilhelm, T.A., Maxwell, S.M., Wagner, D., Bowen, B.W., Sheppard, C.R., Taei, S.M., Teroroko, T., Moffitt, R. \& Gaymer, C.F. 2013. One size does not fit all: the emerging frontier in large-scale marine conservation. Marine Pollution Bulletin, 77, 7-10.

Toral-Granda, V. 2008. Population status, fisheries and trade of sea cucumbers in Latin America and the Caribbean. In: Toral-Granda, V. (ed.) Sea cucumbers, a global review of fisheries and trade. Rome: FAO Fisheries and Aquaculture.

von Heland, F. \& Clifton, J. 2014. Whose threat counts? Conservation narratives in the Wakatobi National Park. Conservation and Society.

Wagner, D., Wilhelm, A., Friedlander, A., Skeat, A., Sheppard, A., Bowen, B., Gaymar, C., Sheppard, C., San Martin, G., Wright, I., Philibotte, J., Parks, J., Bosanquet, J., Brider, J., Aiona, K., Morishige, K., Wright-Koteka, L., Lewis, N., Brownie, N., Kosaki, R., Rotjan, R., Jamieson, R., Toonen, R., Constantine, R., van Dijken, S., Anderson, S., Taei, S., Temata, T., Carruthers, T., Durbin, T., Teroroko, T., Short, T., W., T. \& Basher, Z. 2013. A shared research agenda for large-scale marine protected areas.

White, A.T., Courtney, C.A. \& Salamanca, A. 2002. Experience with marine protected area planning and management in the Philippines. Coastal Management, 30, 1-26.

Wilhelm, T.A., Sheppard, C.R., Sheppard, A.L., Gaymer, C.F., Parks, J., Wagner, D. \& Lewis, N. 2014. Large marine protected areas-advantages and challenges of going big. Aquatic Conservation: Marine and Freshwater Ecosystems, 24, 24-30.

Wolff, M., Schuhbauer, A. \& Castrejón, M. 2012. A revised strategy for the monitoring and management of the Galapagos sea cucumber Isostichopus fuscus (Aspidochirotida: Stichopodidae). Revista de Biologia Tropical, 60, 539-551.

Young, H.S., Maxwell, S.M., Conners, M.G. \& Shaffer, S.A. 2015. Pelagic marine protected areas protect foraging habitat for multiple breeding seabirds in the central Pacific.

Biological Conservation, 181, 226-235.

Young, O.R. 2002. The institutional dimensions of environmental change: fit, interplay, and scale, MIT press. 
S1. Full list of designated large Marine Protected Areas $\left(>10,000 \mathrm{~km}^{2}\right)$, ordered from oldest to newest. LMPAs that fulfilled our selection criteria (1: Primary goal of biodiversity conservation; 2: Large; 3: > 5 years active management; 4: Enough data available to assess key outcomes) and were included in our study are marked in bold. The rationale for LMPAs that appear to fit our criteria but were not used in our study has been noted. Information from MPAtlas.org.

\begin{tabular}{|c|c|c|c|c|}
\hline LMPA name & $\begin{array}{l}\text { Date } \\
\text { designated }\end{array}$ & $\operatorname{Size}\left(\mathbf{k m}^{2}\right)$ & $\begin{array}{l}\text { Included } \\
(\mathbf{Y} / \mathbf{N})\end{array}$ & Rationale \\
\hline East Svalbard Nature Reserves & 1973 & 52,365 & $\mathbf{Y}$ & \\
\hline Greenland National Park & 1974 & 110,600 & $\mathrm{~N}$ & $\begin{array}{l}\text { Not enough } \\
\text { data }\end{array}$ \\
\hline Great Barrier Reef Marine Park & 1975 & 344,400 & $\mathbf{Y}$ & \\
\hline $\begin{array}{l}\text { Dominican Republic Marine Mammal } \\
\text { Sanctuary }\end{array}$ & 1986 & 66,670 & $\mathrm{~N}$ & $\begin{array}{l}\text { Not enough } \\
\text { data }\end{array}$ \\
\hline Cenderawasih Bay National Park & 1990 & 13,852 & $\mathbf{Y}$ & \\
\hline $\begin{array}{l}\text { Central California National Marine } \\
\text { Sanctuaries }\end{array}$ & 1992 & 27,645 & $\mathbf{Y}$ & \\
\hline Franz Josef Land & 1994 & 26,000 & $\mathrm{~N}$ & $\begin{array}{l}\text { No active } \\
\text { management } \\
\text { of the marine } \\
\text { area }\end{array}$ \\
\hline Wakatobi National Park & 1996 & 13,395 & $\mathbf{Y}$ & \\
\hline Galapagos Marine Reserve & 1998 & 133,000 & $\mathbf{Y}$ & \\
\hline Great Australian Bight Marine Park & 1998 & 19,395 & $\mathbf{Y}$ & \\
\hline Macquarie Island Marine Reserve & 1999 & 162,060 & $\mathbf{Y}$ & \\
\hline Pelagos Sanctuary & 2001 & 87,492 & $\mathrm{~N}$ & $\begin{array}{l}\text { No active } \\
\text { management }\end{array}$ \\
\hline Heard Island and McDonald Islands & 2002 & 64,598 & $\mathbf{Y}$ & \\
\hline Seaflower MPA & 2005 & 65,000 & $\mathbf{Y}$ & \\
\hline $\begin{array}{l}\text { Papahanaumokuakea Marine } \\
\text { National Monument }\end{array}$ & 2006 & $362,073 *$ & $\mathbf{Y}$ & \\
\hline Phoenix Islands Protected Area & 2006 & 408,224 & $\mathrm{~N}$ & $\begin{array}{l}\text { Management } \\
\text { plan } \\
\text { introduced in } \\
2010\end{array}$ \\
\hline Raja Ampat MPA Network & 2007 & 11,859 & $\mathbf{Y}$ & \\
\hline \multicolumn{5}{|c|}{ LMPAs below had not had active management for five years (at time of coding) } \\
\hline $\begin{array}{l}\text { Marianas Trench Marine National } \\
\text { Monument }\end{array}$ & 2009 & 250,488 & $\mathrm{~N}$ & $\begin{array}{l}\text { Management } \\
\text { in } \\
\text { development }\end{array}$ \\
\hline $\begin{array}{l}\text { Pacific Remote Islands Marine National } \\
\text { Monument }\end{array}$ & 2009 & $1,271,525$ & $\mathrm{~N}$ & $\begin{array}{l}\text { Management } \\
\text { in } \\
\text { development }\end{array}$ \\
\hline Rose Atoll Marine National Monument & 2009 & 34,838 & $\mathrm{~N}$ & $\begin{array}{l}\text { Management } \\
\text { in }\end{array}$ \\
\hline
\end{tabular}




\begin{tabular}{|l|l|l|l|l|}
\hline & & & & development \\
\hline $\begin{array}{l}\text { South Orkney Islands Southern Shelf } \\
\text { MPA }\end{array}$ & 2010 & 93,818 & N & $\begin{array}{l}\text { Management } \\
\text { introduced in } \\
2013\end{array}$ \\
\hline Chagos MPA & 2010 & 640,000 & N & $\begin{array}{l}\text { Interim } \\
\text { management } \\
\text { framework } \\
\text { 2014-15 }\end{array}$ \\
\hline Charlie-Gibbs South High Seas MPA & 2010 & 145,420 & N & \\
\hline Josephine Seamount High Seas MPA & 2010 & 19,370 & & \\
\hline Marine Park of Mayotte & 2010 & 68,345 & $\mathrm{~N}$ & \\
\hline $\begin{array}{l}\text { Mid-Atlantic Ridge North of the Azores } \\
\text { (MARNA) }\end{array}$ & 2010 & 93,416 & $\mathrm{~N}$ & \\
\hline Milne Seamount Complex MPA & 2010 & 20,913 & $\mathrm{~N}$ & \\
\hline $\begin{array}{l}\text { Australia Commonwealth Marine } \\
\text { Reserves (n=18)* }\end{array}$ & 2012 & $1,871,668$ & $\mathrm{~N}$ & \\
\hline Charlie-Gibbs North High Seas MPA & 2012 & 178,651 & $\mathrm{~N}$ & \\
\hline Gloriosos Islands Marine Nature Park & 2012 & 48,350 & $\mathrm{~N}$ & \\
\hline $\begin{array}{l}\text { South Georgia and South Sandwich } \\
\text { Islands Marine Protected Area }\end{array}$ & 2012 & $1,070,000$ & $\mathrm{~N}$ & \\
\hline Fagatale Bay National Marine Sanctuary & 2012 & 35,174 & $\mathrm{~N}$ & \\
\hline Prince Edward Islands MPA & 2013 & 180,000 & $\mathrm{~N}$ & \\
\hline Natural Park of the Coral Sea & 2014 & $1,292,962$ & $\mathrm{~N}$ & \\
\hline Savu Sea (Tirosa Batek) & 2014 & 29,454 & $\mathrm{~N}$ & \\
\hline Motu Motivo Hiva Marine Park & 2015 & 720,000 & $\mathrm{~N}$ & \\
\hline Nazca Desventuradas & 2015 & 297,000 & $\mathrm{~N}$ & \\
\hline Palau National Marine Sanctuary & 2015 & 500,000 & $\mathrm{~N}$ & \\
\hline Pitcairn Islands Marine Reserve & 2015 & 834,334 & $\mathrm{~N}$ & \\
\hline Kermadec Ocean Sanctuary & 2016 & 620,000 & $\mathrm{~N}$ & \\
\hline $\begin{array}{l}\text { Marae Moana Cook Islands (Cook } \\
\text { Islands Marine Park) }\end{array}$ & 2016 & $1,100,000$ & $\mathrm{~N}$ & \\
\hline
\end{tabular}

* On $26^{\text {th }}$ August 2016 Papahānaumokuākea Marine National Monument was extended to $1,508,870$ $\mathrm{km}^{2}$.

** Australia Commonwealth Marine Reserves $>10,000 \mathrm{~km}^{2}$ : Abrolhos; Argo-Rowley Terrace; Central Eastern; Coral Sea; Flinders; Freycinet; Gascoyne; Kimberly; Lord Howe; Murray; Norfolk; Oceanic Shoals; Shark Bay; South Tasman Rise; South-west Corner; Tasman Fracture; Western Eyre; Zeehan. 


\section{S2. Descriptions of the variables analysed for each thematic hypothesis.}

\begin{tabular}{|c|c|c|}
\hline Variable & $\begin{array}{l}\text { Question (and } \\
\text { definition) }\end{array}$ & Options \\
\hline $\begin{array}{l}\text { Commons } \\
\text { mobility }\end{array}$ & $\begin{array}{l}\text { What is the mobility of } \\
\text { this commons? }\end{array}$ & $\begin{array}{l}\text { High: Commons is highly migratory and capable of } \\
\text { regularly travelling great distances ( }>500 \mathrm{~km} \text {, but often } \\
>5000 \mathrm{~km} \text { ), and is typically considered a 'migratory } \\
\text { species'; } \\
\text { Medium: Commons may be fairly site specific but } \\
\text { capable of larger movements (e.g. ontogenetic } \\
\text { migration), or have a relatively large home-range >1- } \\
500 \mathrm{~km} \text {; } \\
\text { Sessile/Low: Commons is sessile or can move small } \\
\text { distances (within } 1 \mathrm{~km})\end{array}$ \\
\hline $\begin{array}{l}\text { Commons } \\
\text { productivity }\end{array}$ & $\begin{array}{l}\text { How productive is the } \\
\text { commons? }\end{array}$ & $\begin{array}{l}\text { Very productive: The unit or system produces at very } \\
\text { high levels, and can withstand extensive human } \\
\text { extraction and use, typical of modern large-scale } \\
\text { industrial operations, for a period of time; } \\
\text { Moderately Productive: The unit or system produces at } \\
\text { moderate levels, and can withstand an equivalently } \\
\text { moderate level of human extraction and use; } \\
\text { Poorly productive: The unit or system produces at very } \\
\text { low levels, and cannot withstand much human } \\
\text { extraction and use beyond subsistence levels. }\end{array}$ \\
\hline $\begin{array}{l}\text { Ecological } \\
\text { resilience }\end{array}$ & $\begin{array}{l}\text { Given the current state } \\
\text { of the system, how } \\
\text { ecologically resilient is } \\
\text { this commons to the } \\
\text { threats that it can be } \\
\text { expected to face? }\end{array}$ & $\begin{array}{l}\text { Highly resilient; } \\
\text { Moderately resilient; } \\
\text { Poorly resilient }\end{array}$ \\
\hline $\begin{array}{l}\text { Resource } \\
\text { market value }\end{array}$ & $\begin{array}{l}\text { If it is traded in a } \\
\text { market, how high is the } \\
\text { market value of this } \\
\text { resource? }\end{array}$ & $\begin{array}{l}\text { High: Only very few actors have the purchasing power } \\
\text { to purchase the commons (e.g., rare but highly } \\
\text { desirable fish, e.g., bluefin tuna); } \\
\text { Medium: Some actors have purchasing power to } \\
\text { purchase the commons } \\
\text { Low: Almost all actors have the purchasing power to }\end{array}$ \\
\hline
\end{tabular}




\begin{tabular}{|c|c|c|}
\hline & & $\begin{array}{l}\text { purchase the commons (e.g., a very common, small } \\
\text { fish such as sardines) }\end{array}$ \\
\hline $\begin{array}{l}\text { Distance to } \\
\text { market }\end{array}$ & $\begin{array}{l}\text { What is the approximate } \\
\text { distance between the } \\
\text { boundaries of this } \\
\text { governance system and } \\
\text { the nearest market in } \\
\text { which the commons } \\
\text { within this system are } \\
\text { sold? (Only if commons } \\
\text { are sold). } \\
\text { Definition: Calculate or } \\
\text { estimate the shortest } \\
\text { distance from the } \\
\text { governance boundary to } \\
\text { the nearest market for } \\
\text { the resources contained } \\
\text { within the system. Major } \\
\text { market could be a } \\
\text { trading centre, large } \\
\text { town or provincial } \\
\text { capital and even a local } \\
\text { middleman, but does not } \\
\text { refer to local subsistence } \\
\text { use. }\end{array}$ & $\begin{array}{l}\text { Less than } 10 \mathrm{~km} ; \\
\text { Between } 10-100 \mathrm{~km} \\
\text { Between } 100 \mathrm{~km}-1000 \mathrm{~km} \text {; } \\
\text { More than } 1000 \mathrm{~km}\end{array}$ \\
\hline \multicolumn{3}{|c|}{ Thematic hypothesis 2 - Attributes of the MPA } \\
\hline Variable & $\begin{array}{l}\text { Question (and } \\
\text { definition) }\end{array}$ & Options \\
\hline No take & $\begin{array}{l}\text { What percentage of the } \\
\text { area of this protected } \\
\text { area is covered by no } \\
\text { take zones (IUCN Ia, Ib, } \\
\text { and II)? }\end{array}$ & Numerical \\
\hline Age & $\begin{array}{l}\text { What is the total age } \\
\text { (years) of this } \\
\text { governance system from }\end{array}$ & Numerical \\
\hline
\end{tabular}




\begin{tabular}{|c|c|c|}
\hline & $\begin{array}{l}\text { when it was originally } \\
\text { designated to the end of } \\
\text { this interaction? }\end{array}$ & \\
\hline Snapshot age & $\begin{array}{l}\text { What is the total age } \\
\text { (years) of this } \\
\text { governance system from } \\
\text { the start of the } \\
\text { interaction being } \\
\text { considered to the end? }\end{array}$ & Numerical \\
\hline Size & $\begin{array}{l}\text { What is the total size } \\
(\mathrm{km} 2) \text { of this protected } \\
\text { area at the end of this } \\
\text { snapshot? }\end{array}$ & Numerical \\
\hline $\begin{array}{l}\text { Efficient } \\
\text { enforcement }\end{array}$ & $\begin{array}{l}\text { What is the extent of } \\
\text { compliance to } \\
\text { regulations that restrict } \\
\text { fishing, both through } \\
\text { overt policing and } \\
\text { through community } \\
\text { support for regulations? }\end{array}$ & $\begin{array}{l}\text { High: Appears to be well enforced, although } \\
\text { clandestine poaching may occur; } \\
\text { Medium: A moderate level of policing attempted, } \\
\text { although infractions were apparent; } \\
\text { Low: Little attempt at control, a 'paper park' }\end{array}$ \\
\hline Isolated & $\begin{array}{l}\text { Does the marine } \\
\text { protected area protect an } \\
\text { ecologically coherent } \\
\text { area (i.e., limited or } \\
\text { protected by deep water } \\
\text { or sand) within no-take } \\
\text { zones? }\end{array}$ & $\begin{array}{l}\text { High: MPA zone isolated from fishing areas by depth } \\
(.25 \mathrm{~m}) \text { or sand barriers of at least } 20 \mathrm{~m} \text { width. (if an } \\
\text { island is all no take then it is classed as high); } \\
\text { Medium: A small ( } 1-20 \%) \text { percentage of zone } \\
\text { boundary breached by continuous shallow reef habitat; } \\
\text { Low: Shallow }(.25 \mathrm{~m}) \text { reef habitat extends continuously } \\
\text { across MPA boundary }\end{array}$ \\
\hline $\begin{array}{l}\text { CAR } \\
\text { principles }\end{array}$ & $\begin{array}{l}\text { Were the ecological } \\
\text { principles of } \\
\text { Comprehensive, } \\
\text { Adequate, } \\
\text { Representative } \\
\text { considered in the design } \\
\text { of this MPA? }\end{array}$ & $\begin{array}{l}\text { Yes: The CAR principles were fully considered in the } \\
\text { design of the MPA and applied in practice, and the } \\
\text { MPA is considered an appropriate size, shape and } \\
\text { management level to ensure the ecological viability } \\
\text { and integrity of the populations, species and } \\
\text { communities, which have been selected as } \\
\text { conservation features; } \\
\text { Partially: Consideration was given to the CAR } \\
\text { principles in the design of the MPA but their }\end{array}$ \\
\hline
\end{tabular}




\begin{tabular}{|c|c|c|}
\hline & & $\begin{array}{l}\text { application was compromised, either through size, } \\
\text { shape (some features bisected), or insufficient } \\
\text { management or protection; } \\
\text { No: The CAR principles were not considered in the } \\
\text { design of the MPA (i.e. little or no consideration was } \\
\text { given to the size and/or shape of the sites, and/or entire } \\
\text { features are not sufficiently protected); }\end{array}$ \\
\hline \multicolumn{3}{|c|}{ Thematic hypothesis 3 - social and governance attributes: the institutional design principles } \\
\hline Variable & $\begin{array}{l}\text { Question (and } \\
\text { definition) }\end{array}$ & Options \\
\hline $\begin{array}{l}\text { Actor group } \\
\text { boundary } \\
\text { clarity }\end{array}$ & $\begin{array}{l}\text { Are there clear rules } \\
\text { that are followed } \\
\text { about who and who } \\
\text { isn't a member of } \\
\text { this group? }\end{array}$ & $\begin{array}{l}\text { No boundaries: Entire lack of common understanding } \\
\text { regarding group membership; } \\
\text { Unclear boundaries: Some of the members of this group } \\
\text { are aware of who is and who isn't a member, and there is } \\
\text { some enforcement of any rules associated with } \\
\text { membership; } \\
\text { Clear boundaries: The great majority of the members of } \\
\text { this group are aware of who is and who isn't a member, and } \\
\text { there is strong enforcement of any rules associated with } \\
\text { membership }\end{array}$ \\
\hline $\begin{array}{l}\text { Actor group } \\
\text { boundary } \\
\text { fuzziness }\end{array}$ & $\begin{array}{l}\text { Is membership in } \\
\text { this actor group } \\
\text { subject to ongoing } \\
\text { negotiations (fuzzy } \\
\text { boundaries)? Or are } \\
\text { the boundaries the } \\
\text { group more rigid? }\end{array}$ & $\begin{array}{l}\text { Rigid: Changes in membership and the rights and } \\
\text { obligations associated with membership change } \\
\text { infrequently and are not changeable based on short to } \\
\text { medium-term fluctuations; } \\
\text { Fuzzy: Changes in membership and the rights and } \\
\text { obligations associated with membership can change in a } \\
\text { relatively ad hoc basis, based on the needs of users and } \\
\text { potential members to access the benefits associated with } \\
\text { membership }\end{array}$ \\
\hline $\begin{array}{l}\text { Commons } \\
\text { boundaries }\end{array}$ & $\begin{array}{l}\text { Are the boundaries } \\
\text { that define the } \\
\text { spatial extent of this } \\
\text { commons clearly } \\
\text { defined and highly } \\
\text { visible? }\end{array}$ & $\begin{array}{l}\text { Very unclear boundaries: The boundaries of a commons are } \\
\text { difficult to identify with precision. That is usually the case } \\
\text { with the boundaries of migratory species and with many } \\
\text { groundwater aquifer systems; } \\
\text { Somewhat unclear boundaries: The boundaries of a } \\
\text { commons are somewhat identifiable. } \\
\text { Clear boundaries: The limits of the commons are }\end{array}$ \\
\hline
\end{tabular}




\begin{tabular}{|c|c|c|}
\hline & & $\begin{array}{l}\text { physically evident. This includes both natural elements and } \\
\text { human-made artifacts that constrain the commons. Natural } \\
\text { elements would include the biogeophysical limits of a } \\
\text { watershed. Human-made artifacts would include fences that } \\
\text { constrain a population of species. }\end{array}$ \\
\hline $\begin{array}{l}\text { Commons } \\
\text { boundary } \\
\text { negotiability }\end{array}$ & $\begin{array}{l}\text { How negotiable is } \\
\text { access by non- } \\
\text { members of this } \\
\text { actor group to this } \\
\text { environmental } \\
\text { commons? }\end{array}$ & $\begin{array}{l}\text { Rigid: Negotiations to access this environmental commons } \\
\text { by non-members are not possible or not fruitful; } \\
\text { Moderate: Some negotiations can be made by non- } \\
\text { members; } \\
\text { Negotiable: Ad-hoc negotiations can be and are commonly } \\
\text { made by non-members to obtain access to this } \\
\text { environmental common }\end{array}$ \\
\hline $\begin{array}{l}\text { Outsider } \\
\text { exclusion }\end{array}$ & $\begin{array}{l}\text { To what extent are } \\
\text { members of this } \\
\text { commons user } \\
\text { group able to } \\
\text { exclude non- } \\
\text { members (outsiders) } \\
\text { from using this } \\
\text { commons? }\end{array}$ & $\begin{array}{l}\text { No exclusion: Outsiders face no impediments from the user } \\
\text { group in their attempts to use the commons; } \\
\text { Some exclusion: Members of a commons using actor group } \\
\text { somewhat effectively prevent non-members for using a } \\
\text { commons that they use; } \\
\text { Total exclusion: Users are able to prevent the great majority } \\
\text { to all incursion by outsiders }\end{array}$ \\
\hline $\begin{array}{l}\text { Social- } \\
\text { ecological fit }\end{array}$ & $\begin{array}{l}\text { To what extent } \\
\text { (low, medium, or } \\
\text { high) do the } \\
\text { institutional } \\
\text { arrangements of this } \\
\text { governance system } \\
\text { fit well with the } \\
\text { ecological or } \\
\text { physical features of } \\
\text { the commons on } \\
\text { which they are } \\
\text { implemented? }\end{array}$ & $\begin{array}{l}\text { High: If achieve all three of the following, } \\
\text { Medium: If achieve two of the following, } \\
\text { Low: If achieve zero or one of the following: } \\
\text { a. Does the governance system encompass the distribution } \\
\text { or range of the resource (spatial fit) or do mechanisms exist } \\
\text { to ensure their consistency across the range of this } \\
\text { resource? } \\
\text { b. Are the rules for the use of resources within the MPA } \\
\text { consistent with the current scientific consensus? } \\
\text { c. Does the governance system include rules or mechanisms } \\
\text { to address threats to resources from other environmental } \\
\text { commons (i.e. species or invasive species) social-ecological } \\
\text { systems (i.e. land areas/runoff) and human activities (i.e. oil } \\
\text { and mineral exploration affecting habitat)? (exclude climate } \\
\text { change threats) }\end{array}$ \\
\hline Proportionality & Is there general & Yes: Costs and benefits are balanced in a way that is \\
\hline
\end{tabular}




\begin{tabular}{|c|c|c|}
\hline $\begin{array}{l}\text { (of costs and } \\
\text { benefits) }\end{array}$ & $\begin{array}{l}\text { proportionality } \\
\text { between the amount } \\
\text { of costs group } \\
\text { members incur and } \\
\text { the amount of } \\
\text { benefits received? }\end{array}$ & $\begin{array}{l}\text { expected and considered legitimate by members of the } \\
\text { group } \\
\text { No: Costs and benefits are unbalanced } \\
\text { (Not about the size or profitability, or outcomes - just the } \\
\text { proportional distribution within a user group) }\end{array}$ \\
\hline $\begin{array}{l}\text { Participation } \\
\text { in rule making }\end{array}$ & $\begin{array}{l}\text { How high is the } \\
\text { level of } \\
\text { participation of this } \\
\text { actor group in the } \\
\text { process that } \\
\text { determines how this } \\
\text { environmental } \\
\text { commons is } \\
\text { governed? }\end{array}$ & $\begin{array}{l}\text { High: Actors have active engagement in decision-making } \\
\text { processes, including, but not limited to the ability to } \\
\text { meaningfully make changes in important rules when } \\
\text { appropriate; } \\
\text { Medium: Actors have some engagement, e.g. the actor } \\
\text { group may participate in electing representatives who have } \\
\text { some say in rule changing, but the actor group itself does } \\
\text { not participate; } \\
\text { Low: Members of the actor group do not have any ability to } \\
\text { participate in rule changing processes (although they may } \\
\text { be informed of these processes, or have access to extreme } \\
\text { ways of changing rules, such as, e.g. violent protests or acts } \\
\text { of resistance of the type described by Scott (1985)) }\end{array}$ \\
\hline $\begin{array}{l}\text { Self } \\
\text { monitoring }\end{array}$ & $\begin{array}{l}\text { Does this actor } \\
\text { group monitor its } \\
\text { own activities with } \\
\text { respect to the use of } \\
\text { this commons? }\end{array}$ & $\begin{array}{l}\text { Yes: Members of this actor group monitor each others' } \\
\text { behavior towards the commons; } \\
\text { No: Members of this actor group do not monitor each } \\
\text { others' behavior towards the commons }\end{array}$ \\
\hline $\begin{array}{l}\text { Environmental } \\
\text { monitoring }\end{array}$ & $\begin{array}{l}\text { How much } \\
\text { environmental } \\
\text { monitoring of this } \\
\text { commons does this } \\
\text { actor group engage } \\
\text { in? }\end{array}$ & $\begin{array}{l}\text { High: This actor group engages in frequent and systematic } \\
\text { monitoring efforts that are sufficient to adequately; observe } \\
\text { changes in commons conditions; } \\
\text { Moderate: This actor group engages in some monitoring of } \\
\text { the conditions of this commons; } \\
\text { Low: This actor group engages in very little to no } \\
\text { monitoring of the conditions of this commons. } \\
\text { Consequently, it cannot detect changes in commons } \\
\text { conditions }\end{array}$ \\
\hline Self sanctions & $\begin{array}{l}\text { Are sanctions } \\
\text { applied by and to } \\
\text { the members of this }\end{array}$ & $\begin{array}{l}\text { Graduated sanctions; } \\
\text { Non-graduated sanctions; } \\
\text { No sanctions }\end{array}$ \\
\hline
\end{tabular}




\begin{tabular}{|c|c|c|}
\hline & $\begin{array}{l}\text { group for violations } \\
\text { of rules regarding } \\
\text { extraction or } \\
\text { emission? And if so, } \\
\text { are these sanctions } \\
\text { graduated } \\
\text { (increasing with } \\
\text { severity and } \\
\text { repetition of } \\
\text { offenses)? }\end{array}$ & $\begin{array}{l}\text { (Sanctions can include a diversity of forms of social } \\
\text { shunning, fines, extra regulations or the complete } \\
\text { prohibition of resource use or pollution emissions (Ostrom } \\
1990) \text { ) }\end{array}$ \\
\hline $\begin{array}{l}\text { External } \\
\text { recognition }\end{array}$ & $\begin{array}{l}\text { Within this } \\
\text { governance system, } \\
\text { do larger } \\
\text { governmental } \\
\text { jurisdictions (i.e. } \\
\text { International } \\
\text { agreements, Nation } \\
\text { states) recognize the } \\
\text { autonomy of lower- } \\
\text { level jurisdictions } \\
\text { (States, regions, } \\
\text { communities), and } \\
\text { their right to make } \\
\text { decisions regarding } \\
\text { this commons? }\end{array}$ & $\begin{array}{l}\text { High: Complete recognition of larger governmental } \\
\text { jurisdictions' recognizing lower level jurisdictions' } \\
\text { autonomy in decision-making regarding the commons in } \\
\text { question; } \\
\text { Moderate: Some recognition; } \\
\text { Low: No recognition }\end{array}$ \\
\hline Multiple levels & $\begin{array}{l}\text { Does this } \\
\text { governance system } \\
\text { contain multiple } \\
\text { levels, with each } \\
\text { level having a set of } \\
\text { actors who conduct } \\
\text { tasks with respect to } \\
\text { the management of } \\
\text { this commons? If } \\
\text { so, is there active } \\
\text { coordination across }\end{array}$ & $\begin{array}{l}\text { Single-level governance; } \\
\text { Coordination among multiple levels; Multiple levels but no } \\
\text { coordination }\end{array}$ \\
\hline
\end{tabular}




\begin{tabular}{|c|c|c|c|}
\hline & \multicolumn{2}{|c|}{ these levels, or not? } & \\
\hline Compliance & \multicolumn{2}{|c|}{$\begin{array}{l}\text { Do members of this } \\
\text { actor group follow } \\
\text { the rules of this } \\
\text { governance system } \\
\text { with respect to the } \\
\text { emission or } \\
\text { appropriation of this } \\
\text { commons? }\end{array}$} & $\begin{array}{l}\text { No: This actor group does not usually comply with the } \\
\text { formal rules of a governance system that regulate the } \\
\text { emission or appropriation of a given commons; } \\
\text { Somewhat: This actor group sometimes complies with } \\
\text { rules, or complies with only a subset of the rules; } \\
\text { Yes: This actor group almost always or always complies } \\
\text { with formal rules }\end{array}$ \\
\hline $\begin{array}{l}\text { Conflict } \\
\text { resolution }\end{array}$ & \multicolumn{2}{|c|}{$\begin{array}{l}\text { Are mechanisms in } \\
\text { place to address } \\
\text { conflicts that arise } \\
\text { over the use of this } \\
\text { commons by this } \\
\text { actor group? }\end{array}$} & $\begin{array}{l}\text { Yes: Conflict resolution mechanisms, whether formal and/or } \\
\text { informal, exist; } \\
\text { No: No conflict resolution mechanism exists }\end{array}$ \\
\hline \multicolumn{4}{|c|}{ Thematic hypothesis 4 - social attributes of the MPA: Participation } \\
\hline Variable & $\begin{array}{l}\text { Question (and } \\
\text { definition) }\end{array}$ & & ions \\
\hline $\begin{array}{l}\text { Participation } \\
\text { in rule making }\end{array}$ & $\begin{array}{l}\text { How high is the } \\
\text { level of } \\
\text { participation of } \\
\text { this actor group } \\
\text { in the process } \\
\text { that determines } \\
\text { how this } \\
\text { environmental } \\
\text { commons is } \\
\text { governed? }\end{array}$ & & $\begin{array}{l}h \text { : Actors have active engagement in decision-making } \\
\text { cesses, including, but not limited to the ability to } \\
\text { aningfully make changes in important rules when } \\
\text { ropriate; } \\
\text { dium: Actors have some engagement, e.g. the actor group } \\
\text { y participate in electing representatives who have some say in } \\
\text { changing, but the actor group itself does not participate; } \\
v \text { : Members of the actor group do not have any ability to } \\
\text { ticipate in rule changing processes (although they may be } \\
\text { ormed of these processes, or have access to extreme ways of } \\
\text { nging rules, such as, e.g. violent protests or acts of resistance } \\
\text { he type described by Scott (1985)) }\end{array}$ \\
\hline $\begin{array}{l}\text { Participation } \\
\text { in protected } \\
\text { area siting }\end{array}$ & $\begin{array}{l}\text { How high was } \\
\text { the level of } \\
\text { participation of } \\
\text { this actor group } \\
\text { or their } \\
\text { representatives }\end{array}$ & & $\begin{array}{l}h: \text { The actor group is in charge of the siting of the MPA with } \\
\text { vithout the support of the lead management agency; } \\
\text { dium: The lead management agency consults the actor group } \\
\text { ing the decision-making process; } \\
v \text { : The lead management agency informs the actor group of } \\
\text { in decisions; }\end{array}$ \\
\hline
\end{tabular}




\begin{tabular}{|c|c|c|}
\hline & $\begin{array}{l}\text { in siting of the } \\
\text { marine } \\
\text { protected area? }\end{array}$ & $\begin{array}{l}\text { None: The lead management agency does not seek input from } \\
\text { the actor group }\end{array}$ \\
\hline $\begin{array}{l}\text { Participation } \\
\text { in protected } \\
\text { area zoning }\end{array}$ & $\begin{array}{l}\text { How high was } \\
\text { the level of } \\
\text { participation of } \\
\text { this actor group } \\
\text { or their } \\
\text { representatives } \\
\text { in the (most } \\
\text { recent) zoning } \\
\text { of this marine } \\
\text { protected area? }\end{array}$ & $\begin{array}{l}\text { High: The actor group is in charge of zoning of the MPA with or } \\
\text { without the support of the lead management agency; } \\
\text { Medium: The lead management agency consults the actor group } \\
\text { during the decision-making process; } \\
\text { Low: The lead management agency informs the actor group of } \\
\text { their decisions; } \\
\text { None: The lead management agency does not seek input from } \\
\text { the actor group }\end{array}$ \\
\hline $\begin{array}{l}\text { Participation } \\
\text { in } \\
\text { environmental } \\
\text { monitoring }\end{array}$ & $\begin{array}{l}\text { How high is the } \\
\text { level of } \\
\text { participation of } \\
\text { this actor group } \\
\text { or their } \\
\text { representatives } \\
\text { in } \\
\text { environmental } \\
\text { monitoring? }\end{array}$ & $\begin{array}{l}\text { High: The actor group is in charge of the environmental } \\
\text { monitoring of the commons with or without the support of the } \\
\text { lead management agency; } \\
\text { Medium: The lead management agency consults the actor group } \\
\text { during the decision-making process; } \\
\text { Low: The lead management agency informs the actor group of } \\
\text { their decisions; } \\
\text { None: The lead management agency does not seek input from } \\
\text { the actor group }\end{array}$ \\
\hline $\begin{array}{l}\text { Participation } \\
\text { in social } \\
\text { monitoring } \\
\text { (enforcement) }\end{array}$ & $\begin{array}{l}\text { How high is the } \\
\text { level of } \\
\text { participation of } \\
\text { this commons } \\
\text { user group or } \\
\text { their } \\
\text { representatives } \\
\text { in social } \\
\text { monitoring } \\
\text { (enforcement)? }\end{array}$ & $\begin{array}{l}\text { High: The actor group is in charge of social monitoring } \\
\text { (enforcement) of the commons with or without the support of } \\
\text { the lead management agency; } \\
\text { Medium: The lead management agency consults the actor group } \\
\text { during the decision-making process; } \\
\text { Low: The lead management agency informs the actor group of } \\
\text { their decisions; } \\
\text { None: The lead management agency does not seek input from } \\
\text { the actor group }\end{array}$ \\
\hline
\end{tabular}


S3. Summary of the key components coded for the fisheries and ecosystem health interactions for each large-scale MPA. To ensure consistency across cases, we focused on coding the most influential or impactful governance system, user group, and manager for each interaction at the scale of the MPA. Snapshot refers to a time period where management was fairly consistent (e.g., after legislative or policy reform).

\begin{tabular}{|c|c|c|c|c|}
\hline Case & \multicolumn{2}{|c|}{ Fisheries-interaction } & \multicolumn{2}{|c|}{ Ecosystem health-interaction } \\
\hline Central & Governing org.: & Fisheries managers & Governing org.: & Managers \\
\hline California & Gov. system: & Management plan & Gov. system: & Management plan \\
\hline National Marine & Snapshot: & $1992-2015$ & Snapshot: & $1992-2015$ \\
\hline Sanctuaries & User: & Commercial fisher & User: & Researchers \\
\hline (USA) & Commons: & Groundfish habitat & Commons: & Rocky intertidal \\
\hline Cenderawasih & Governing org.: & Co-managers & Governing org.: & Co-managers \\
\hline Bay National & Gov. system: & System of Laws & Gov. system: & System of Laws \\
\hline Park (Indonesia) & Snapshot: & $2002-2015$ & Snapshot: & $2002-2015$ \\
\hline & User: & Artisanal fisher & User: & Artisanal fisher \\
\hline & Commons: & Target reef fish & Commons: & Coral cover \\
\hline Galapagos & Governing org. & Managers & Governing org.: & Managers \\
\hline Marine Reserve & Gov. system: & Management plan & Gov. system: & Management plan \\
\hline (Ecuador) & Snapshot: & $1998-2015$ & Snapshot: & $1998-2015$ \\
\hline & User: & Artisanal fisher & User: & Tourism \\
\hline & Commons: & Sea cucumber & Commons: & Sharks \\
\hline Great Australian & Governing org.: & Managers & Governing org.: & Managers \\
\hline Bight Marine & Gov. system: & Management plan & Gov. system: & Management plan \\
\hline Park (Australia) & Snapshot: & $2000-2012$ & Snapshot: & $2000-2012$ \\
\hline & User: & Commercial fisher & User: & Commercial fisher \\
\hline & Commons: & Southern bluefin tuna & Commons: & Australian sea lion \\
\hline Great Barrier & Governing org. & Co-managers & Governing org.: & Co-managers \\
\hline Reef Marine Park & Gov. system: & Management plan & Gov. system: & Management plan \\
\hline
\end{tabular}




\begin{tabular}{|c|c|c|c|c|}
\hline \multirow[t]{4}{*}{ (Australia) } & Snapshot: & $2004-2015$ & Snapshot: & $2004-2015$ \\
\hline & User: & Commercial fisher & User: & Recreational fisher \\
\hline & Governing org & Fisheries managers & User: & \\
\hline & Commons: & Target fish & Commons: & Coral cover \\
\hline \multirow[t]{5}{*}{ Heard Island and } & Governing org.: & Fisheries managers & Governing org.: & Managers \\
\hline & Gov. system: & Management plan x2 & Gov. system: & Management plan \\
\hline & Snapshot: & $2002-2012$ & Snapshot: & $2002-2012$ \\
\hline & User: & Commerical fishers & User: & \\
\hline & Commons: & Toothfish & Commons: & King penguin \\
\hline \multirow{5}{*}{$\begin{array}{l}\text { Macquarie Island } \\
\text { Marine Reserve } \\
\text { (Australia) }\end{array}$} & Governing org.: & Fisheries managers & Governing org. & Managers \\
\hline & Gov. system: & Management plan x3 & Gov. system: & $\begin{array}{l}\text { Management plan } \\
\text { x2 }\end{array}$ \\
\hline & Snapshot: & $2001-2015$ & Snapshot: & $2001-2015$ \\
\hline & User: & Commercial fishers & User: & \\
\hline & Commons: & Toothfish & Commons: & King penguin \\
\hline \multirow[t]{5}{*}{ Papahānaumokuā } & Governing org.: & Co-managers & Governing org.: & Co-managers \\
\hline & Gov. system: & Management plan & Gov. system: & Management plan \\
\hline & Snapshot: & $2006-2015$ & Snapshot: & $2006-2015$ \\
\hline & User: & & User: & Researchers \\
\hline & Commons: & Lobster & Commons: & Trophic density \\
\hline \multirow{5}{*}{$\begin{array}{l}\text { Raja Ampat MPA } \\
\text { network } \\
\text { (Indonesia) }\end{array}$} & Governing org.: & Co-managers & Governing org.: & Co-managers \\
\hline & Gov. system: & System of Laws & Gov. system: & System of Laws \\
\hline & Snapshot: & $2009-2015$ & Snapshot: & $2009-2015$ \\
\hline & User: & Artisanal fisher & User: & Artisanal fisher \\
\hline & Commons: & Target reef fish & Commons: & Coral cover \\
\hline \multirow{2}{*}{$\begin{array}{l}\text { Seaflower MPA } \\
\text { (Colombia) }\end{array}$} & Governing org.: & Manager & Governing org.. & Manager \\
\hline & Gov. system: & System of Laws & Gov. system: & System of Laws \\
\hline
\end{tabular}




\begin{tabular}{|c|c|c|c|c|}
\hline & Snapshot: & $2005-2015$ & Snapshot: & $2005-2015$ \\
\hline & User: & Artisanal fisher & User: & Artisanal fisher \\
\hline & Commons: & Groupers (6 species) & Commons: & Coral cover \\
\hline \multirow{5}{*}{$\begin{array}{l}\text { Svalbard Nature } \\
\text { Reserves } \\
\text { (Norway) }\end{array}$} & Governing org.: & Co-managers & Governing org.: & Co-managers \\
\hline & Gov. system: & System of Laws & Gov. system: & System of Laws \\
\hline & Snapshot: & $2002-2012$ & Snapshot: & $2002-2012$ \\
\hline & User: & Commercial fishers & User: & Tourism \\
\hline & Commons: & Shrimp & Commons: & Polar bear \\
\hline \multirow{5}{*}{$\begin{array}{l}\text { Wakatobi } \\
\text { National Park } \\
\text { (Indonesia) }\end{array}$} & Governing org.: & Co-managers & Governing org.: & Co-managers \\
\hline & Gov. system: & Management plan & Gov. system: & Management plan \\
\hline & Snapshot: & $2008-2015$ & Snapshot: & $2008-2015$ \\
\hline & User: & Artisanal fisher & User: & Artisanal fisher \\
\hline & Commons: & Fish spawning & Commons: & Coral cover \\
\hline
\end{tabular}


S4. The total variation (\%) explained by the first two dimensions from the analyses (PCA/MCA)

for each thematic hypothesis and corresponding outcome. (N.B. each outcome and hypothesis corresponds to a separate unit of analysis).

\begin{tabular}{|l|l|l|l|l|}
\hline Thematic hypothesis & $\begin{array}{l}\text { Fisheries } \\
\text { trend }\end{array}$ & $\begin{array}{l}\text { Fisheries- } \\
\text { associated } \\
\text { wellbeing }\end{array}$ & $\begin{array}{l}\text { Ecosystem } \\
\text { health trend }\end{array}$ & $\begin{array}{l}\text { Test } \\
\text { used }\end{array}$ \\
\hline $\begin{array}{l}\text { 1: Ecological and economic attributes } \\
\text { of species and ecosystems }\end{array}$ & 50.12 & 53.19 & 58.72 & MCA \\
\hline 2: Attributes of the MPA & 67.22 & 59.54 & 49.31 & PCA \\
\hline $\begin{array}{l}\text { 3: Social and governance attributes: } \\
\text { the institutional design principles }\end{array}$ & 54.10 & 56.12 & 49.31 & MCA \\
\hline $\begin{array}{l}\text { 4: Social and governance attributes: } \\
\text { participation }\end{array}$ & 74.51 & 79.74 & 74.7 & MCA \\
\hline
\end{tabular}

S5. The categorical variables in thematic hypothesis 1 - ecological and economic attributes of species or ecosystem (productivity, market value, distance to market) that significantly contribute to the first dimension in the MCA for the fisheries trend data. The outcome variable (fisheries trend) was also correlated to the first dimension indicating a strong correlation.

Ecological resilience and mobility did not contribute to the formation of the first dimension. $\left(\mathrm{R}^{2}\right.$ and $\mathrm{p}$-values are calculated using ANOVA in the dimdesc function in FactoMineR).

\begin{tabular}{|l|l|l|}
\hline & $\mathrm{R}^{2}$ & $\mathrm{p}$-value \\
\hline Productivity & 0.92 & $<0.01$ \\
\hline Fisheries trend (outcome) & $\mathbf{0 . 7 5}$ & $<\mathbf{0 . 0 1}$ \\
\hline Market value & 0.75 & $<0.01$ \\
\hline Distance to market & 0.68 & $<0.05$ \\
\hline
\end{tabular}

S6. 2D visual representation of the relationship between the fisheries trend outcome (improved, same, worse), and the variables in thematic hypothesis 1 - ecological and economic attributes of the species or system (productivity, mobility, ecological resilience, market value, distance to market). Variable categories that were significant correlated to the trend are coloured based on their correlation. Variable categories that were non-significant are in grey. The plot is based on the MCA 
output with $95 \%$ confidence ellipses are for the fisheries trend categories, with the larger symbol noting the centre of the ellipse.

\section{S7 Supplementary Results:}

This section details the full descriptions of the dimensions from all analyses (MCA/PCA for each thematic hypothesis, interaction, and outcome), including instances where no association between the outcome and dimensions was found. Results are ordered by the four thematic hypotheses, and are presented by outcome for: fisheries trend, fisheries associated wellbeing, and ecosystem health trend. Results focus on the first two dimensions from the MCA or PCA and the total amount of variation explained by the first two dimensions is shown in brackets for each hypothesis and outcome. The description of the dimensions first shows the variables that are linked to the dimensions, followed by the variable categories that are linked to the dimensions. Where an outcome was found to be significantly correlated with a dimension it has been highlighted in bold.

The dimension description is the output from the dimdesc function (from the FactoMineR package: Lê et al. 2008), which identifies the most correlated variables with a given dimension (Husson et al.

2010). Only significant variables are shown $(\mathrm{p}<0.10)$.

\section{Thematic hypothesis 1- Ecological and economic attributes of the species or ecosystem}

1.1 Fisheries - trend (total variation explained by first two dimensions: $50 \%$ ):

Description of the First Dimension by the categorical variables

\begin{tabular}{llcl} 
& R2 & p.value & \\
\cline { 1 - 2 } productivity & 0.92 & $<0.001$ & \\
trend & & 0.75 & 0.004 \\
market value & 0.75 & 0.004 & \\
distance to market & 0.68 & 0.036 &
\end{tabular}

Description of the First Dimension by variable categories

\begin{tabular}{lcll} 
& Estimate & p.value & \\
\cline { 1 - 2 } productivity_low & 0.8 & $<0.001$ & \\
market value_high & 0.87 & 0.001 & \\
fishery trend worse & 0.90 & 0.001 & \\
market distance $>1000 \mathrm{~km}$ & 1.03 & 0.016 & \\
mobility_high & 1.01 & 0.082 & \\
fishery trend improved & -0.62 & 0.082 \\
market value_med & -0.60 & 0.040 & \\
productivity_med & -0.82 & $<0.001$ &
\end{tabular}


Description of the Second Dimension by the categorical variables

\begin{tabular}{llll} 
& R2 & p.value & \\
\hline Distance to market & 0.78 & 0.010 & \\
mobility & 0.62 & 0.021 & \\
fishery trend & \multicolumn{2}{c}{0.62} & 0.022 \\
market value & 0.55 & 0.041 &
\end{tabular}

Description of the Second Dimension by variable categories

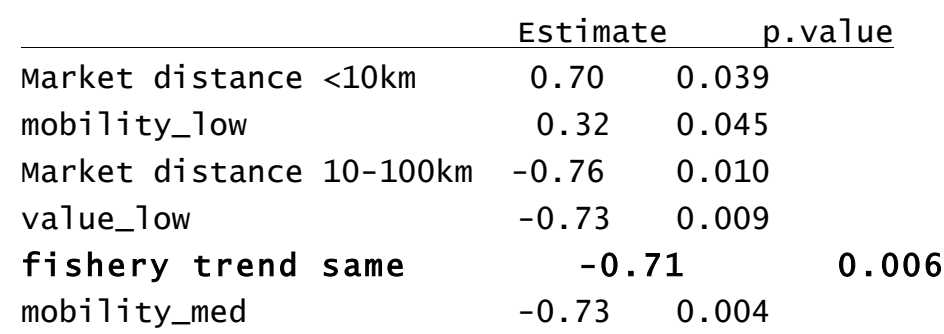

1.2 Fisheries - social wellbeing (total variation explained by first two dimensions: $53 \%$ ):

Description of the First Dimension by the categorical variables

\begin{tabular}{lll} 
& R2 & p.value \\
\hline productivity & 0.87 & $<0.001$ \\
market value & 0.75 & 0.007 \\
distance to market & 0.63 & 0.092
\end{tabular}

Description of the First Dimension by variable categories

\begin{tabular}{lcc} 
& Estimate & p.value \\
\hline productivity_low & 0.78 & $<0.001$ \\
market value_high & 0.86 & 0.003 \\
Market distance $>1000 \mathrm{~km}$ & 0.93 & 0.045 \\
mobility_high & 1.02 & 0.088 \\
Market distance $<10$ & -0.71 & 0.087 \\
We11being trend worse & -0.67 & 0.037 \\
Market value_med & -0.69 & 0.035 \\
productivity_med & -0.78 & $<0.001$
\end{tabular}

Description of the Second Dimension by the categorical variables

\begin{tabular}{lll} 
& R2 & p.value \\
\hline Distance to market & 0.88 & 0.004 \\
Market value & 0.62 & 0.035 \\
mobility & 0.61 & 0.038
\end{tabular}

Description of the Second Dimension by variable categories

\begin{tabular}{lcl} 
& Estimate & \multicolumn{1}{c}{ p.value } \\
\hline Wellbeing trend worse & 0.52 & 0.069 \\
mobility_low & 0.28 & 0.085 \\
less10 & 0.72 & 0.091 \\
We11being trend same & -0.48 & 0.098 \\
Market value_low & -0.79 & 0.009
\end{tabular}


$\begin{array}{lll}\text { mobility_med } & -0.77 & 0.008 \\ \text { market distance } 10-100 & -1.01 & 0.004\end{array}$

1.3 Ecosystem health - trend (total variation explained by first two dimensions: $59 \%$ ):

Description of the First Dimension by the categorical variables

\begin{tabular}{llc} 
& R2 & P.value \\
\hline productivity & 0.92 & $<0.001$ \\
mobility & 0.84 & $<0.001$ \\
distance to market & 0.85 & 0.001
\end{tabular}

Description of the First Dimension by variable categories

\begin{tabular}{|c|c|c|}
\hline & \multicolumn{2}{|c|}{ Estimate } \\
\hline productivity_med & 0.85 & 0.003 \\
\hline mobility_high & 0.60 & 0.010 \\
\hline more1000 & 1.16 & 0.017 \\
\hline 10 to 100 & -1.06 & 0.013 \\
\hline mobi1ity_low & -0.98 & $<0.001$ \\
\hline productivity_high & -1.00 & $<0.001$ \\
\hline
\end{tabular}

Description of the Second Dimension by the categorical variables

\begin{tabular}{lll} 
& R2 & p.value \\
\hline productivity & 0.62 & 0.013 \\
distance to market & 0.63 & 0.039 \\
resilience & 0.29 & 0.069 \\
mobility & 0.44 & 0.076
\end{tabular}

Description of the Second Dimension by variable categories

\begin{tabular}{lrr} 
& \multicolumn{2}{c}{ Estimate } \\
\hline productivity_low & 0.86 & 0.004 \\
mobility_med & 0.83 & 0.019 \\
100to1000 & 0.79 & 0.020 \\
Resilience_poor & 0.40 & 0.069 \\
Resilience_mod & -0.40 & 0.069 \\
more1000 & -0.84 & 0.031
\end{tabular}

Thematic hypothesis 2 - Attributes of the MPA:

2.1 Fisheries - trend (total variation explained by first two dimensions: 67\%):

Description of the First Dimension by the quantitative variables

\begin{tabular}{lcc} 
& correlation & p.value \\
\hline Notake & 0.92 & $<0.001$ \\
Isolated & 0.83 & 0.001 \\
CAR & 0.79 & 0.002 \\
Size & 0.64 & 0.026
\end{tabular}

Description of the Second Dimension by the quantitative variables

\begin{tabular}{ccc} 
& correlation & p.value \\
\hline Age & 0.76 & 0.004
\end{tabular}


$\begin{array}{lll}\text { Snapshot_age } & 0.71 & 0.010 \\ \text { enforcement } & 0.51 & 0.090\end{array}$

Description of the Second Dimension by the variable categories for the fisheries trend outcome (categ orical): (fishery trend) and the categories of this categorical variable

\begin{tabular}{|c|c|c|c|c|}
\hline \multicolumn{4}{|c|}{ Estimate } & p.value \\
\hline $\mathrm{Fi}$ & $t r$ & impro & 1.55 & 0.0 \\
\hline Fishery & trend & same & -1.29 & 0.016 \\
\hline
\end{tabular}

2.2 Fisheries - social wellbeing (total variation explained by first two dimensions:60\%):

Description of the First Dimension by the quantitative variables

\begin{tabular}{lcc} 
& correlation & p.value \\
\hline Notake & 0.90 & $<0.001$ \\
Isolated & 0.81 & 0.004 \\
CAR & 0.81 & 0.004 \\
Age & -0.57 & 0.085
\end{tabular}

Description of the Second Dimension by the quantitative variables

\begin{tabular}{lcc} 
& correlation & p.value \\
\hline Age & 0.71 & 0.021 \\
Size & 0.71 & 0.022 \\
Snapshot_age & 0.65 & 0.041
\end{tabular}

2.3 Ecosystem health - trend (total variation explained by first two dimensions: $49 \%$ ):

Description of the First Dimension by the quantitative variables

\begin{tabular}{lcl} 
& correlation & p.value \\
\hline Notake & 0.92 & $<0.001$ \\
Isolated & 0.83 & 0.001 \\
CAR & 0.79 & 0.002 \\
Size & 0.64 & 0.026
\end{tabular}

Description of the Second Dimension by the quantitative variables

\begin{tabular}{lcc} 
& correlation & p.value \\
\hline Age & 0.76 & 0.004 \\
Snapshot_age & 0.72 & 0.009 \\
enforcement & 0.51 & 0.090
\end{tabular}

Thematic hypothesis 3 - social and governance attributes: the institutional design principles:

3.1 Fisheries - trend (total variation explained by first two dimensions: 54\%)

Description of the First Dimension by the categorical variables

\begin{tabular}{lcc} 
& R2 & p.value \\
\hline Compliance & 0.65 & 0.003 \\
Outsider exclusion & 0.77 & 0.003 \\
selfmonitoring & 0.64 & 0.003 \\
self_sanctions & 0.64 & 0.003 \\
participation & 0.67 & 0.011 \\
external recognition & 0.51 & 0.057
\end{tabular}


Description of the First Dimension by variable categories

\begin{tabular}{lcc} 
& Estimate & p.value \\
\hline Compliance_high & 0.52 & 0.003 \\
self_sanctions_Graduated & 0.67 & 0.003 \\
selfmonitoring_Yes & 0.67 & 0.003 \\
outsider_exclusion_some & 0.77 & 0.003 \\
participation_high & 0.72 & 0.020 \\
single leve1 & 0.64 & 0.064 \\
commons boundary negotiability_rigid & 0.62 & 0.072 \\
coordinated levels & -0.64 & 0.064 \\
external recognition_low & -0.68 & 0.022 \\
participation_low & -0.71 & 0.022 \\
outsider_exclusion_no & -0.69 & 0.005 \\
self_sanctions_No & -0.67 & 0.003 \\
selfmonitoring_No & -0.67 & 0.003 \\
Compliance_some & -0.52 & 0.003
\end{tabular}

Description of the Second Dimension by the categorical variables

\begin{tabular}{lll}
\multicolumn{2}{c}{ R2 } & \multicolumn{1}{c}{ p.value } \\
\cline { 1 - 2 } External recognition & 0.93 & $<0.001$ \\
Fishery trend & 0.73 & 0.005 \\
Environmental monitoring & 0.44 & 0.026 \\
outsider_exclusion & 0.60 & 0.026 \\
self-monitoring & 0.34 & 0.059 \\
self-sanctions & 0.34 & 0.059 \\
participation & 0.45 & 0.091 \\
costs.benefits & 0.28 & 0.093
\end{tabular}

Description of the Second Dimension by variable categories

\begin{tabular}{|c|c|c|c|}
\hline & Estimate & & value \\
\hline External recognition_high & 0.54 & 0.015 & \\
\hline fishery trend same & 0.52 & 0.018 & \\
\hline environmental monitoring_low & 0.39 & 0.026 & \\
\hline se1f_sanctions_Graduated & 0.44 & 0.059 & \\
\hline selfmonitoring_Yes & 0.44 & 0.059 & \\
\hline outsider_exclusion_some & 0.73 & 0.059 & \\
\hline costs.benefits_No & 0.32 & 0.093 & \\
\hline costs.benefits_Yes & -0.32 & 0.093 & \\
\hline Social-ecological_fit_med & -0.50 & 0.083 & \\
\hline self_sanctions_No & -0.44 & 0.059 & \\
\hline se1fmonitoring_No & -0.44 & 0.059 & \\
\hline outsider_exclusion_total & -0.76 & 0.040 & \\
\hline envir_monitor_med & -0.39 & 0.026 & \\
\hline participation_med & -0.52 & 0.024 & \\
\hline fishery trend worse & & -0.63 & 0.003 \\
\hline external recognition_mod & -0.73 & 0.000 & \\
\hline
\end{tabular}

3.2 Fisheries - social wellbeing (total variation explained by first two dimensions: $56 \%$ )

Description of the First Dimension by the categorical variables 


\begin{tabular}{lcc} 
& R2 & p.value \\
\hline Compliance & 0.77 & 0.001 \\
costs.benefits & 0.66 & 0.004 \\
participation & 0.64 & 0.029 \\
Social-ecological fit & 0.61 & 0.038 \\
External recognition & 0.60 & 0.040 \\
outsider_exclusion & 0.56 & 0.059 \\
environmental monitoring & 0.34 & 0.079
\end{tabular}

Description of the First Dimension by categories

\begin{tabular}{|c|c|c|c|}
\hline & Estimate & p.value & \\
\hline Compliance_high & 0.60 & 0.001 & \\
\hline costs.benefits_Yes & 0.57 & 0.004 & \\
\hline Social-ecological fit_med & 0.76 & 0.009 & \\
\hline commons_boundary negotiability_rigi & id $\quad 0.69$ & 0.065 & \\
\hline wel1being improved & 0.63 & & 0.073 \\
\hline external recognition_mod & 0.47 & 0.079 & \\
\hline environmental monitoring_med & 0.40 & 0.079 & \\
\hline environmental monitoring_low & -0.40 & 0.079 & \\
\hline Social-ecological fit_low & -0.27 & 0.078 & \\
\hline Wellbeing worse & -0.58 & & 0.077 \\
\hline outsider_exclusion_no & -0.78 & 0.020 & \\
\hline external recognition_low & -0.75 & 0.009 & \\
\hline participation_low & -0.83 & 0.009 & \\
\hline costs.benefits_No & -0.57 & 0.004 & \\
\hline Compliance_some & -0.60 & 0.001 & \\
\hline
\end{tabular}

Description of the Second Dimension by the categorical variables

\begin{tabular}{llr} 
& R2 & p.value \\
\hline External recogntion & 0.95 & $<0.001$ \\
Self-monitoring & 0.54 & 0.016 \\
self_sanctions & 0.54 & 0.016 \\
outsider_exclusion & 0.66 & 0.022 \\
environmental monitoring & 0.49 & 0.024
\end{tabular}

Description of the Second Dimension by variable categories

\begin{tabular}{lrc} 
& Estimate & p.value \\
\hline External recogntion_high & 0.94 & $<0.001$ \\
self_sanctions_Graduated & 0.76 & 0.016 \\
selfmonitoring_Yes & 0.76 & 0.016 \\
outsider_exclusion_some & 1.12 & 0.016 \\
environmenta1_monitoring_1ow & 0.44 & 0.024 \\
external_recognition_mod & -0.66 & 0.024 \\
environmental_monitoring_med & -0.44 & 0.024 \\
self_sanctions_No & -0.76 & 0.016 \\
selfmonitoring_No & -0.76 & 0.016
\end{tabular}

3.3 Ecosystem health - trend (total variation explained by first two dimensions: $49 \%$ ):

Description of the First Dimension by the categorical variables 


\begin{tabular}{llr} 
& R2 & p.value \\
\hline Social-ecological fit & 0.82 & 0.003 \\
costs.benefits & 0.57 & 0.012 \\
user boundaries & 0.51 & 0.020 \\
environmental monitoring & 0.67 & 0.021 \\
participation & 0.65 & 0.024 \\
Compliance & 0.41 & 0.047 \\
Commons boundary negotiability & 0.56 & 0.056 \\
user boundary fuzziness & 0.37 & 0.061 \\
Ecosystem health trend & 0.52 & 0.077
\end{tabular}

Description of the First Dimension by variable categories

\begin{tabular}{lll} 
& Estimate & p.value \\
\hline Environmental monitoring_high & 0.92 & 0.005 \\
Social-ecological fit_high & 0.83 & 0.005 \\
costs.benefits_Yes & 0.51 & 0.012 \\
participation_med & 0.66 & 0.013 \\
commons_bound_nego_mod & 1.06 & 0.020 \\
user_boundaries_unclear & 0.75 & 0.020 \\
ecos hea1th trend improved & 0.98 & 0.020 \\
Compliance_high & 0.50 & 0.047 \\
user_boundary fuzziness_fuzzy & 0.48 & 0.061 \\
user_boundary fuzziness_rigid & -0.48 & 0.061 \\
Compliance_med & -0.50 & 0.047 \\
participation_low & -0.61 & 0.047 \\
Social-ecological fit_low & -0.71 & 0.022 \\
user_boundaries_clear & -0.75 & 0.020 \\
costs.benefits_No & -0.51 & 0.012
\end{tabular}

Description of the Second Dimension by the categorical variables

\begin{tabular}{lll} 
& \multicolumn{1}{c}{ R2 } & \multicolumn{1}{c}{ p.value } \\
\hline participation & 0.93 & $<0.001$ \\
self-monitoring & 0.76 & $<0.001$ \\
Compliance & 0.45 & 0.033
\end{tabular}

Description of the Second Dimension by variable categories

\begin{tabular}{lcl} 
& Estimate & p.value \\
\hline selfmonitoring_No & 0.55 & 0.001 \\
Compliance_med & 0.48 & 0.033 \\
participation_low & 0.72 & 0.033 \\
external recognition_low & 0.54 & 0.043 \\
Social-ecological fit_med & -0.45 & 0.084 \\
commons_boundary negotiability_rigid & -0.48 & 0.080 \\
Compliance_high & -0.48 & 0.033 \\
se1fmonitoring_Yes & -0.55 & 0.001 \\
participation_high & -0.82 & 0.001
\end{tabular}

\section{Thematic hypothesis 4 - social attributes of the MPA: Participation:}

4.1 Fisheries - trend (total variation explained by first two dimensions: 75\%): 
Description of the First Dimension by the categorical variables

\begin{tabular}{llr} 
& R2 & p.value \\
\hline MPA zoning & 0.98 & $<0.001$ \\
MPA siting & 0.96 & $<0.001$ \\
social_monitoring & 0.96 & $<0.001$ \\
rule_making & 0.71 & 0.007 \\
environmental monitoring & 0.71 & 0.007
\end{tabular}

Description of the First Dimension by variable categories

\begin{tabular}{|c|c|c|}
\hline \multicolumn{2}{|c|}{ Estimate } & p.value \\
\hline MPA zoning_high & 1.60 & $<0.001$ \\
\hline MPA siting_high & 1.58 & $<0.001$ \\
\hline rule_making_high & 1.18 & 0.001 \\
\hline enviro_monitoring_high & 1.16 & 0.001 \\
\hline social_monitoring_medium & 0.79 & 0.028 \\
\hline social_monitoring_high & 0.79 & 0.028 \\
\hline fishery trend same & & \\
\hline social_monitoring_low & -1.57 & $<0.001$ \\
\hline
\end{tabular}

Description of the Second Dimension by the categorical variables

\begin{tabular}{llc} 
& R2 & p.value \\
\hline rule_making & 0.92 & $<0.001$ \\
MPA zoning & 0.91 & $<0.001$ \\
enviro_monitoring & 0.66 & 0.013 \\
MPA siting & 0.64 & 1.766 \\
fishery trend & 0.59 & 0.029
\end{tabular}

Description of the Second Dimension by variable categories

\begin{tabular}{lccc} 
& Estimate & \multicolumn{2}{c}{ p.value } \\
\cline { 1 - 3 } MPA zoning_low & 0.93 & $<0.001$ & \\
rule_making_low & 0.99 & $<0.001$ & \\
enviro_monitoring_low & 0.75 & 0.013 & \\
MPA siting_low & 0.62 & 0.021 & \\
fishery trend same & 0.63 & & 0.044 \\
enviro_monitoring_medium & -0.76 & 0.011 & \\
fishery trend worse & -0.77 & & 0.011 \\
MPA siting_medium & -0.78 & 0.006 & \\
rule_making_medium & -0.85 & 0.003 & \\
MPA zoning_medium & -0.84 & 0.001 &
\end{tabular}

4.2 Fisheries - social wellbeing (total variation explained by first two dimensions: $80 \%$ ):

Description of the First Dimension by the categorical variables

\begin{tabular}{llr} 
& \multicolumn{2}{c}{ R2 } \\
\hline social_monitoring & 0.94 & $<0.001$ \\
MPA zoning & 0.97 & $<0.001$ \\
MPA siting & 0.95 & $<0.001$ \\
rule_making & 0.59 & 0.044 \\
enviro_monitoring & 0.59 & 0.045
\end{tabular}


Description of the First Dimension by variable categories

\begin{tabular}{lcc} 
& Estimate & p.value \\
\hline MPA zoning_high & 1.98 & $<0.001$ \\
social_monitoring_high & 1.46 & $<0.001$ \\
MPA siting_high & 1.94 & $<0.001$ \\
rule_making_high & 1.16 & 0.011 \\
enviro_monitoring_high & 1.13 & 0.012 \\
we11being improved & 0.97 & 0.045 \\
social_monitoring_low & -1.46 & $<0.001$
\end{tabular}

Description of the Second Dimension by the categorical variables

\begin{tabular}{lrr} 
& \multicolumn{2}{c}{ R2 } \\
\hline rule_making & 0.92 & $<0.001$ \\
MPA zoning & 0.91 & $<0.001$ \\
enviro_monitoring & 0.66 & 0.024 \\
MPA siting & 0.64 & 0.028
\end{tabular}

Description of the Second Dimension by variable categories

\begin{tabular}{|c|c|c|}
\hline & \multicolumn{2}{|c|}{ Estimate } \\
\hline MPA zoning_1ow & 0.83 & $<0.001$ \\
\hline rule_making_1ow & 0.94 & $<0.001$ \\
\hline enviro_monitoring_1ow & 0.71 & 0.016 \\
\hline MPA siting_low & 0.54 & 0.022 \\
\hline enviro_monitoring_medium & -0.73 & 0.013 \\
\hline MPA siting_medium & -0.79 & 0.006 \\
\hline rule_making_medium & -0.81 & 0.003 \\
\hline MPA zoning_medium & -0.85 & $<0.001$ \\
\hline
\end{tabular}

4.3 Ecosystem health - trend (total variation explained by first two dimensions: $75 \%$ ):

Description of the First Dimension by the categorical variables

\begin{tabular}{llr} 
& \multicolumn{2}{c}{ R2 } \\
\hline MPA zoning & 0.93 & $<0.001$ \\
social_monitoring & 0.82 & 0.001 \\
rule_making & 0.85 & 0.003 \\
MPA siting & 0.84 & 0.004 \\
enviro_monitoring & 0.72 & 0.022
\end{tabular}

Description of the First Dimension by variable categories

\begin{tabular}{|c|c|c|}
\hline & \multicolumn{2}{|c|}{ Estimate } \\
\hline MPA zoning_high & 1.36 & 0.001 \\
\hline MPA siting_high & 1.28 & 0.001 \\
\hline rule_making_high & 1.21 & 0.001 \\
\hline social_monitoring_medium & 0.87 & 0.001 \\
\hline enviro_monitoring_high & 0.91 & 0.014 \\
\hline MPA zoning_1ow & -1.02 & 0.062 \\
\hline MPA siting_1ow & -0.80 & 0.055 \\
\hline enviro_monitoring_1ow & -0.86 & 0.019 \\
\hline social_monitoring_1ow & -0.87 & 0.001 \\
\hline
\end{tabular}


Description of the Second Dimension by the categorical variables

\begin{tabular}{lrl} 
& R2 & p.value \\
\hline MPA zoning & 0.80 & 0.008 \\
MPA siting & 0.70 & 0.027 \\
rule_making & 0.58 & 0.074
\end{tabular}

Description of the Second Dimension by variable categories

\begin{tabular}{lrll} 
& \multicolumn{2}{c}{ Estimate } & p.value \\
\hline MPA zoning_low & 0.55 & 0.049 & \\
eco. health trend same & & 0.72 & 0.062 \\
rule_making_low & 0.70 & 0.063 & \\
enviro_monitoring_medium & -0.68 & 0.081 & \\
rule_making_medium & -0.69 & 0.049 & \\
MPA siting_medium & -0.97 & 0.005 & \\
MPA zoning_medium & -0.83 & 0.002 &
\end{tabular}

